\title{
Buried Waste Integrated Demonstration Technology Integration Process
}

\author{
James S. Ferguson \\ JoAnne E. Ferguson
}

April 1992
Idaho National Engineering Laboratory
EG\&Q Idaho, Inc.
Idaho Falls, Idaho 83415

\section{Prepared for the}

U. S. Department of Energy

Office of Environmental Psstoration and Waste Management (EM)

Under DOE Field Office, Idaho

Contract DE-AC07-761DO1570 


\section{BURIED WASTE INTEGRATED DEMONSTRATION \\ TECHNOLOGY INTEGRATION PROCESS \\ EGG-WTD-9928}

Prepared By:

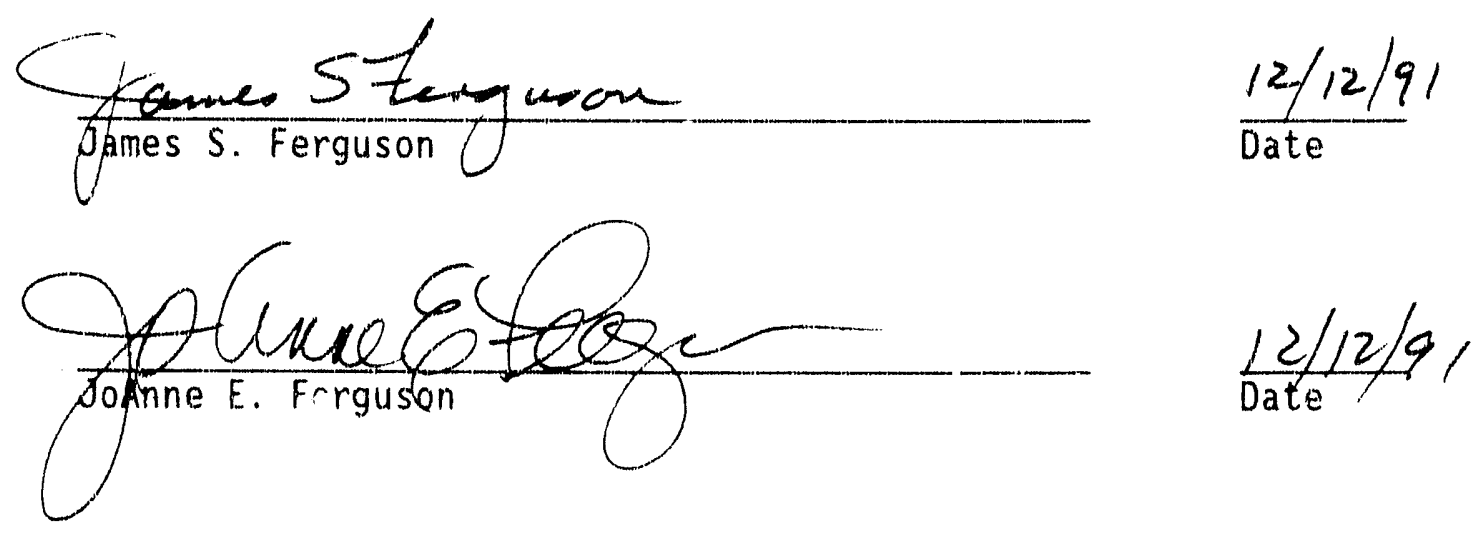

Reviewed and Approved by:

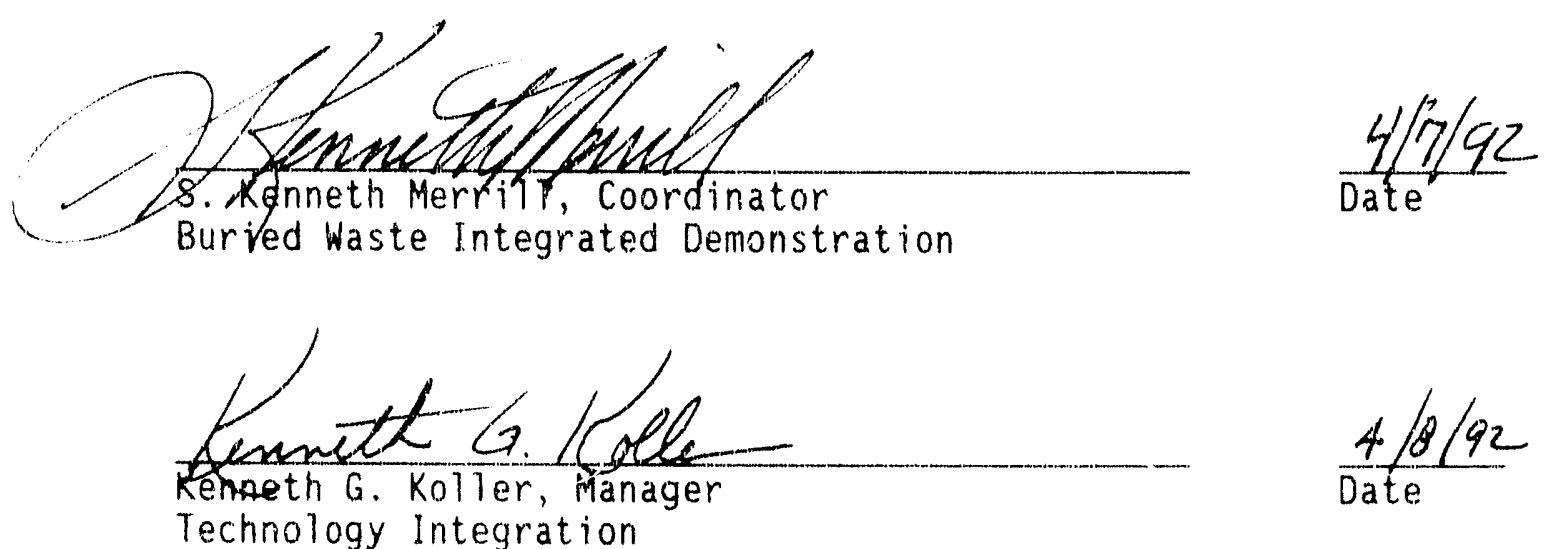




\begin{abstract}
A Technology Integration Process was developed for the Idaho National Engineering Laboratories (INEL) Buried Waste Integrated Demonstration (BWID) Program to facilitate the transter of technology and knowledge from industry, universities, and other Federal agencies into the BWID: to successfully transfer demonstrated technology and knowledge from the BWID to industry, universities, and other Federal agencies; and to share demonstrated technologies and knowledge between Integrated Demonstrations and other Department of Energy (DOE) programs spread throughout the DOE Complex. This document also details specific methods and tools for integrating and transferring technologies into or out of the BWID program.

The document provides background on the BWID program and technology development needs, demonstrates the direction of technology transfer, illustrates current processes for this transfer, and lists points of contact for prospective participants in the BWID technology transfer efforts. The Technology Integration Process was prepared to ensure compliance with the requirements of DOE's Office of Technology Development (OTD).
\end{abstract}




\section{EXECUTIVE SUMMARY}

This document describes the Department of Energy (DOE) Office of Technology Development's (OTD) Integrated Demonstration Technology Integration concept as it is implemented in the Buried Waste Integrated Demonstration (BWID) Frogram at the ldaho National Engineering Laboratory (INEL).

The Federal government's efforts to develop peaceful uses of nuclei $r$ energy through research, development, and production activities at facilities throughout the United States resulted in wastes being buried in the ground or stored for future disposal.

The purpose of the BWID Technology Integration Process is to define technology integration activities and responsibilities that support the BWID Program. The process is designed to facilitate the transfer of technology and knowledge from industry, universities, and other Federal agencies into the BWID; to successfully transfer demonstrated technology and knowledge from the BWID to industry, universities, and other Federal agencies; and to share demonstrated technologies and knowledge between Integrated Demonstrations and other DOE programs spread throughout the DOE Complex. This includes consideration of all technology integration factors that bear on a fullseale restoration-planning, regulatory permitting, and public acceptance. This document also details specific methods and tools for integrating and iransferring technologies into or out of the BWID program.

A major BWID goal is to work with private sector companies to provide mutually beneficial conditions that promote cooperation. This includes providing attractive intellectual property provisions that allow private firms to participate with DOE in its environmental restoration activitics without losing rights to their intellectual property. This approach encourages industry to commercialize technologies developed through partnerships with DOE.

This document provides background on the BWID program and technology development needs, demonstrates the direction of technology transfer, illustrates current processes for this transfer, and lists points of contact for prospective participants in the BWID technology transfer efforts. The Technology integration Process was prepared to ensure compliance with requirements of OTD and to incorporate the services of the Office of Rescarch and Technology Applications to support the BWID program.

A concerted effort has been made to incorporate technology transfer concepts and procedures from OTD decuments. Future revisions sill place more emphasis on: a) new lechnology transfer procedures and incorporating changes to existing procedures to increase the flow of technology to industry, b) regulatory implementation, c) public issue concerns, and d) other methods to strengthen U.S. industrial competitiveness.

Long-Range Plan for Technology Integration Programs, Office of Technology Development, May 1991.

Technology Integration Branch FY 1992 Technology Integration Programs Plan (Draft), Office of Technology Development, October 1991. 
Technology Integration Branch Fiscal Year 1992 Regulatory Coordination Program Management Program Plan (Draft), Office of Tecianology Development, October 1991.

Technology Integration Branch FY 1992 Public Participation Program Management and Implementation Plan (Draft). Office of Technology Development, October 1991. 


\section{ACKNOWLEDGEMENTS}

This document was prepared with the help of the Office of Research Technology Applications of EG\&G Idaho. Inc. The primary contact was Karen Garcia, who provided technical process reviews and information on mechanisms for technology integration. The authors liberally incorporated information from the majority of the documents listed in Appendix $\mathrm{C}$ - References. The authors appreciate the efforts of the preparers of those references. 


\section{CONTENTS}

ABSTRACT $\ldots \ldots \ldots \ldots \ldots \ldots \ldots \ldots \ldots \ldots \ldots \ldots \ldots \ldots \ldots \ldots \ldots \ldots \ldots$

EXECUTIVE SUMMARY $\ldots \ldots \ldots \ldots \ldots \ldots \ldots \ldots \ldots \ldots \ldots \ldots \ldots \ldots$

ACKNOWLEDGEMENTS $\ldots \ldots \ldots \ldots \ldots \ldots \ldots \ldots \ldots \ldots \ldots \ldots \ldots \ldots$ vii

ACRONYMS $\ldots \ldots \ldots \ldots \ldots \ldots \ldots \ldots \ldots \ldots \ldots \ldots \ldots \ldots \ldots \ldots \ldots \ldots \ldots \ldots \ldots$

1. INTRODUCTION $\ldots \ldots \ldots \ldots \ldots \ldots \ldots \ldots \ldots \ldots \ldots \ldots \ldots \ldots \ldots \ldots$

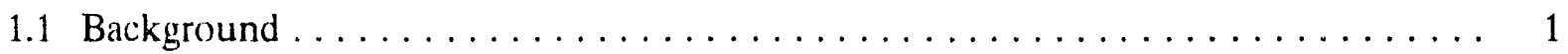

2. MISSION, SCOPE, NEEDS, RESPONSIBILITIES, AND RELATIONSHIPS . . . . . 5

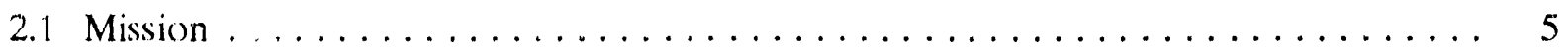

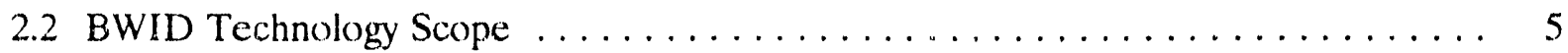

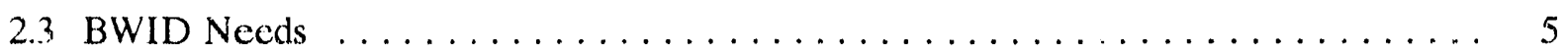

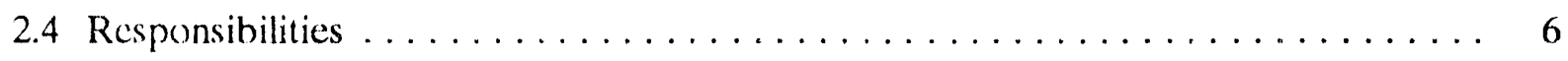

2.4.1 Office of Technology Development (OTD) $\ldots \ldots \ldots \ldots \ldots \ldots \ldots$

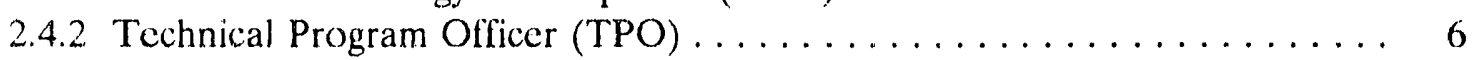

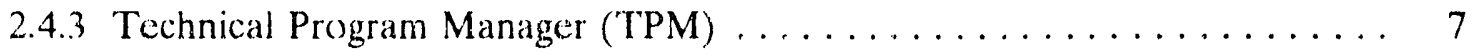

2.4.4 BWID Integrated Demonstration Coordinator (IDC) $\ldots \ldots \ldots \ldots \ldots \ldots . . \ldots$

2.4 .5 Office of Research and Technology Applications (ORTA) $\ldots \ldots \ldots \ldots \ldots$

2.5 Relationship to other Plans and Documents $\ldots \ldots \ldots \ldots \ldots \ldots \ldots \ldots$

3. BURIED WASTE INTEGRATED DEMONSTRATION (BWID) $\ldots \ldots \ldots \ldots \ldots$

3.1 The Integrated Demonstration $\ldots \ldots \ldots \ldots \ldots \ldots \ldots \ldots \ldots \ldots \ldots$

3.2 The Buried Waste Integrated Demonstration $\ldots \ldots \ldots \ldots \ldots \ldots$

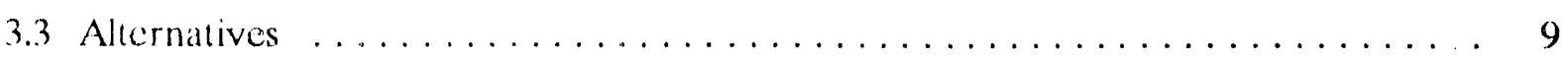

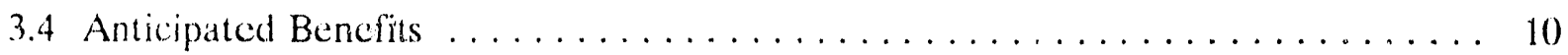


4. TECHNOLOGY INTEGRATION $\ldots \ldots \ldots \ldots \ldots \ldots \ldots \ldots \ldots \ldots \ldots \ldots \ldots$

4.1 Assumptions $\ldots \ldots \ldots \ldots \ldots \ldots \ldots \ldots \ldots \ldots \ldots \ldots \ldots \ldots \ldots \ldots \ldots$

4.2 Technology Integration Components $\ldots \ldots \ldots \ldots \ldots \ldots \ldots \ldots \ldots \ldots \ldots$

4.2.1 Technology Transfer into the BWID $\ldots \ldots \ldots \ldots \ldots \ldots \ldots \ldots$

4.2.2 Sharing of Technology within the DOE Complex ............. 15

4.2.3 Transfer of Demonstrated Technology out of the BWID . . . . . . . 15

5. INTELLECTUAL PROPERTY $\ldots \ldots \ldots \ldots \ldots \ldots \ldots \ldots \ldots \ldots \ldots \ldots \ldots$

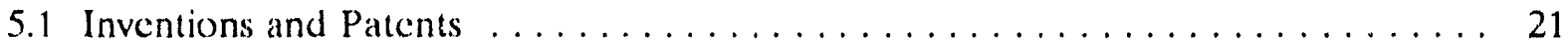

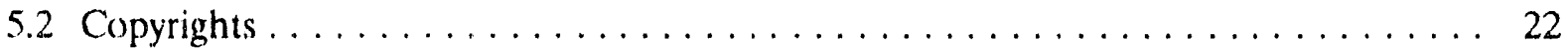

$5.3 W_{\text {ithholding of Funding Agreement Data } \ldots \ldots \ldots \ldots \ldots \ldots \ldots \ldots \ldots \ldots} \ldots \ldots$

Appendix A-Technology Integration Mechanisms $\ldots \ldots \ldots \ldots \ldots \ldots \ldots \ldots \ldots$

Appendix B-BWID Points of Contact $\ldots \ldots \ldots \ldots \ldots \ldots \ldots \ldots \ldots \ldots \ldots \ldots \ldots \ldots \ldots$

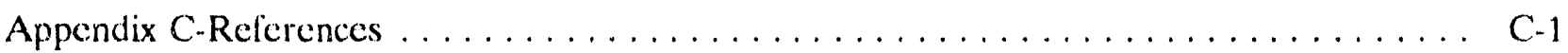

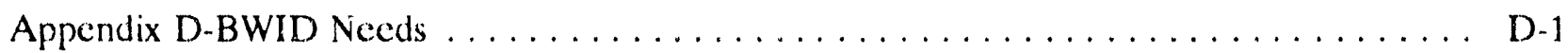

\section{FIGURES}

1. DUE Environmentai Restoration and Waste Management $\ldots \ldots \ldots \ldots \ldots \ldots \ldots \ldots$

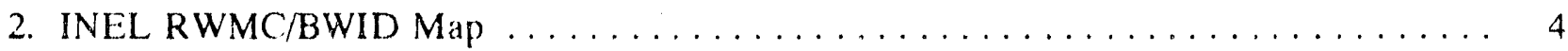

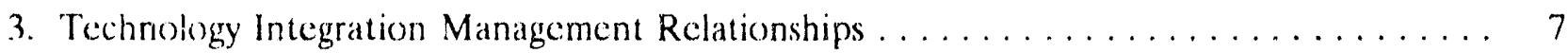

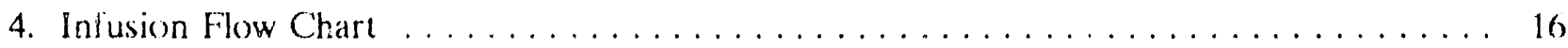

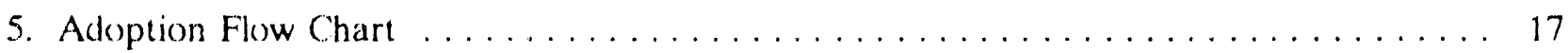

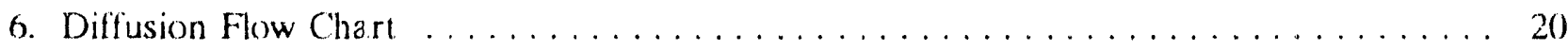




\section{TABLES}

1. Major Milestones for Long-Range Technology Integration Programs $\ldots \ldots \ldots \ldots \ldots$

2. Potential Intellectual Property and Proprietary Issue

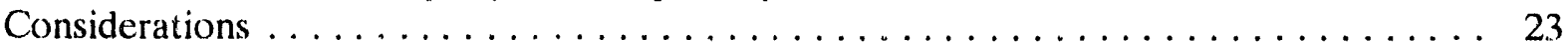

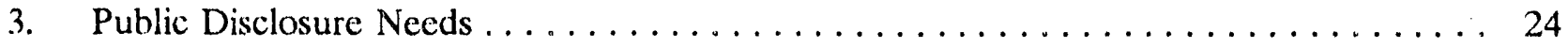

4. Limited Withholding Data Requirements $\ldots \ldots \ldots \ldots \ldots \ldots \ldots \ldots \ldots \ldots \ldots$ 


\section{ACRONYMS}

\begin{tabular}{|c|c|}
\hline $\mathrm{BAA}$ & Broad Agency Amnouncement \\
\hline $\mathrm{BOA}$ & Blarket Order Agreoment \\
\hline BWID & Buried Waste Integrated Demonstration \\
\hline $\mathrm{CBD}$ & Commerce Business Daily \\
\hline $\mathrm{CFR}$ & Code of Federal Regulations \\
\hline CRADA & Cooperative Research and Development Agreement \\
\hline$D \& D$ & Decontamiration and Decommissioning \\
\hline DEAR & Department of Energy Acquisition Regulation \\
\hline DOE & U.S. Department of Energy \\
\hline $\mathrm{EM}$ & Office of Environmental Restoration and Waste Management \\
\hline $\mathrm{ER}$ & Oftice of Environmental Restoration \\
\hline ERP & Environmental Restoration Program \\
\hline ES\&H & Environmental, Safety, and Health \\
\hline ESTSC & Energy Science and Technology Software Center \\
\hline FLC & Federal Laboratory Consortium \\
\hline FOIA & Freedom of Information sct \\
\hline FUSKAP & Formerly Utilized Sites Rcmediation Actions Programs \\
\hline $\mathrm{COCO}$ & Government-owned, Contractor-operated \\
\hline GTCC & Groater Than Class C W Waste \\
\hline$H \perp W$ & High-Level Waste \\
\hline ID & Integrated Demonstration \\
\hline IDC & Integrated Demonstration Coordinator \\
\hline $11: B$ & Invitation for Bid \\
\hline INEL & Idaho National Engineering Laboratory \\
\hline L.LW & Low-Level Waste \\
\hline $\mathrm{M} \& \mathrm{O}$ & Management and Operating (Contractors) \\
\hline $\mathrm{MOU}$ & Memorandum of Understanding \\
\hline ORTA & Office of Research and Technology Applications \\
\hline OTD & Office of Technology Development \\
\hline $\mathrm{PON}$ & Program Opportunity Noiice \\
\hline PRDA & Program Research and Development Annuuncement \\
\hline$R \& D$ & Research and Development \\
\hline RDDT\&E & Research, Development, Demonstration, Testing, and Evaluation \\
\hline RFP & Request for Proposals \\
\hline ROA & Reseasch Opportunity Announcement \\
\hline RWMC & Radioactive Waste Management Complex \\
\hline SBIR & Small Business Innovation Research Programs \\
\hline $\mathrm{SDA}$ & Subsurface Disposal Arca \\
\hline TIP & Technokgy Integration Program \\
\hline TPM & Technical Program Manager \\
\hline TPO & Technical Program Officer \\
\hline TRU & Transuranic Waste \\
\hline TTP & Technical Task Plan \\
\hline UMTRA & Uranium Mill Tailings Remedial Action (Project) \\
\hline
\end{tabular}




\section{Buried Waste Integrated Demonstration Technology Integration Process}

\section{INTRODUCTION}

This document develops a Technology Integration Process for the Buried Waste Integration Program (BWID) and identifies methods that facilitate technology integration for the BWID Program. This process identifies responsibilities in support of BWID Technology Integration, methods to facilitate technology integration endeavors between BWID and outside groups, and primary technology integration points of contact for industry, academia, and other organizations and disciplines.

Technology integration is integral to the success of the BWID in that it supports the BWID mission to develop and demonstrate technologies for the remediation of buried waste at the Idaho National Engineering Laboratory (INEL) Radioactive Waste Management Complex (RWMC) and for Environmental Restoration Programs (ERP) throughout the Department of Energy (DOE) Complex.

DOE is soliciting knowledge and technology from private industries (national and international), universities, and other Federal agencies to solve its unprecedented buried waste problems. Assistance provided by these entities includes expertise in scientific and engineering disciplines, information exchange, and integration of available and emerging technologies from the private sector to remediate. DOE's buried waste better, safer, faster, anc cheaper. Innovative methods to procure technologies from outside the DOE system are being developed and implemented to facilitate the demonstration of technologies applicable to huried waste remediation for development and demonstration at the INEL through the BWID.

Following successful demonstration by the BWID, knowledge and technology will be transferred to private industry for commercial development, and to universities, other Federal agencies, and other DOE laboratories.

\subsection{Background}

DOE and its predecessor agencies conducted nuclear weapons rescarch, development, and production, and development of peaceful uses of nuclear encrgy at many facilities throughout the United States. As a result of these and other operations, wastes have been buried or stored for future disposal. DOE sites with buried waste problems include the Idaho National Engineering Laboratory (INEL). the Hanford Site, the Oak Ridge National Laboratory (ORNL), the Savannath River Site (SRS), the Los Alamos National Laboratory (LANL), the Lawrence Livermore National Laboratory (LLNL.), the Sandia National Laboratory (SNL), and the Nevada Test Site (NTS). Figure 1 is a U.S. map showing the location of these sites.

Early practices allowed the commingling of various types of wastes that later became subject to regulation as hazardous waste. Much of the buried waste throughout the DOE Complex is contaminated with both hazardous and radioactive materials. The buried waste includes transuranic 


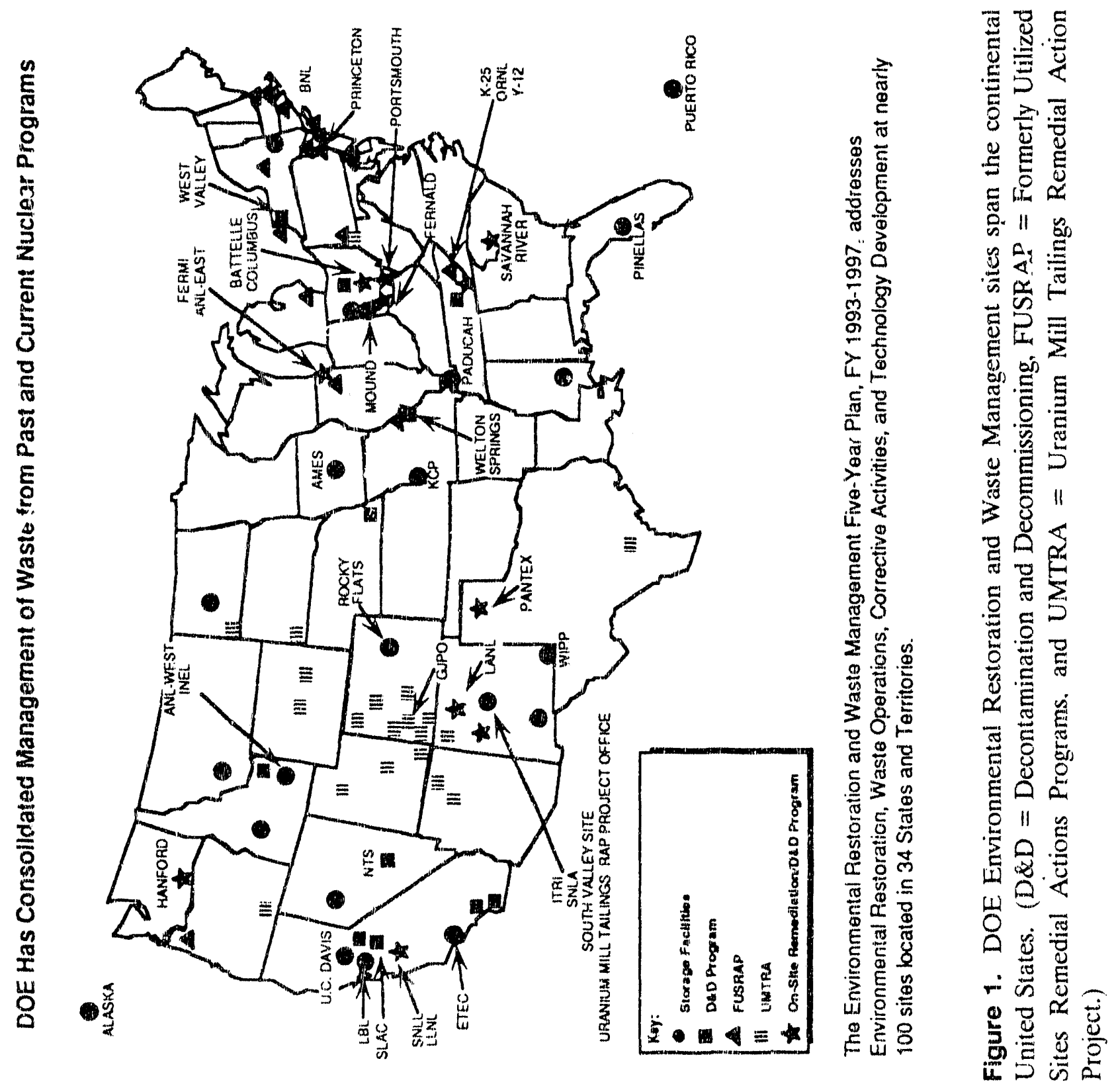


(TRU) waste, low-level radioactive waste (LLW), high-level waste (HLW), Greater-Than-Class-C LLW (GTCC), hazardous waste regulated by 40 Code of Federal Regulations |CFR| 261 mixed TRU waste, and mixed LLW. Many of the original containers have degraded significantly, resulting in contamination of the surrounding soil.

A significant volume (approximately $30 \%$ ) of the DOE-Complex's buried waste is located at the INEL. The majority of the buried waste ai the INEL is located within the Subsurface Disposal Area (SDA) at the Radioactive Waste Managemen Complex (RWMC). Figure 2 illustrates the RWMC and the SDA. The RWMC was established in 1952 s. a controlled area for disposal of waste resulting from INEL's operations; beginning in 1954, TRU waste generated at the Rocky Flats weapons complex was also disposed of at the SDA. The SDA is an 96-acre tract of land with numerous pits, trenches, soil vaults, and one above-ground pad (Pad A) where radioactive and hazardous wastes were buried or stored.

Over two million $\mathrm{ft}^{3}$ of buried waste is located at the RWMC (EGG-WTD-9870, Informal Report, Buried Waste Integrated Demonstration Plan). This includes TRU waste, LLW, HLW, GTCC waste, hazardous waste, and mixed waste. The waste and site characteristics of the RWMC are ressonably representative of all DOE buried-waste sites. This fact allows demonstrations of environmental restoration/remediation technology to be performed at the SDA with confidence that the results will be useful for potential applications at other DOE buried-waste sites.

Environmental restoration projects proceed through the phases of characterization, assessment, remediation, and monitoring. Integrated Demonstrations encompass these same phases and are designed as full-scale pilot environmental restorations. In these demonstrations, alternative technical solutions to specific problems can be tested in parallel and in a context that includes consideration of all technology integration factors that bear on a full-scale restoration--planning, regulatory permitting, and public acceptance. Also, because multiple technologies are tested together, the advantages of one comprehensive remediation system over another can be determined.

An Integrated Demonstration has three aspects. The operational aspect involves all the cradleto-grave phases for an environmental restoration project. The technology filtering aspect involves evaluation and selection of technology from research and development (R\&D) for demonstration, testing, and evaluation (DT\&E) based on criteria derived from the aim 10 implement faster, cheaper, safer, and better technologies. The technology integration aspect involves early and continued interaction among interested states, Federal regulatory bodies, and respective communities to expedite regulatory and public acceptance of innovative technology systems in time for implementation. Technology integration also deals with private industry, universities, and other agencies to evaluate technology in Integrated Demonstrations (ID). Demonstrated technology is transferred to DOE Environmental Restoration and Waste Management (EM) operations, other Federal agencies, and the industrial and international sectors.

The BWID was established to develop and demonstrate technologies to address the remediation of buried waste throughout the DOE Complex. 

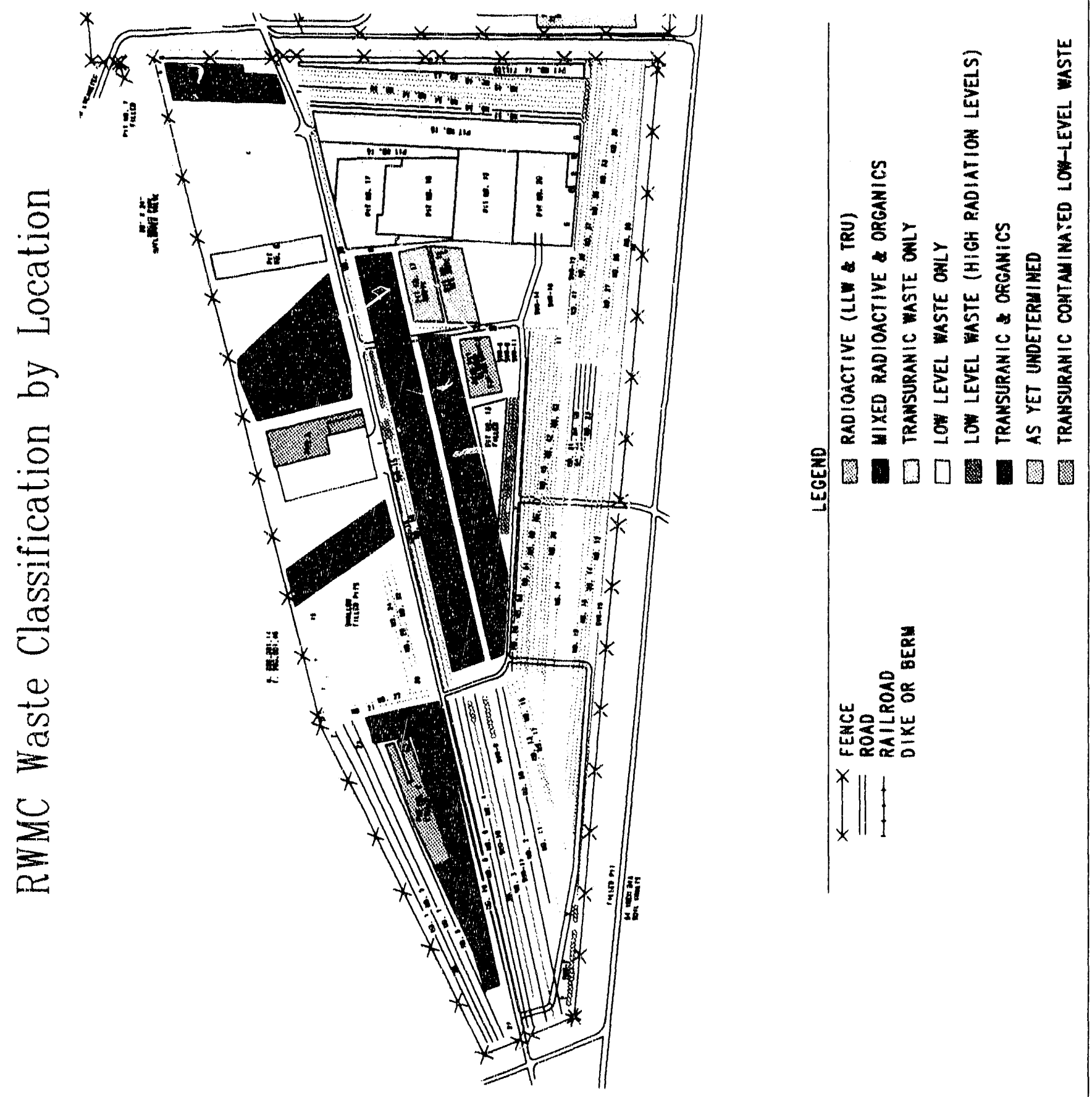

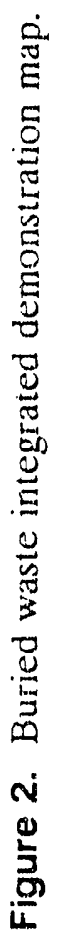




\section{MISSION, SCOPE, NEEDS, RESPONSIBILITIES, AND RELATIONSHIPS}

\subsection{Mission}

BWID's mission is to support, evaluate, demonstrate, and validate a suite of technologies (a comprehensive remediation systems) for the effective and efficient remediation of buried waste.

The BWID Technology Integration mission supports the BWID mission by

- Involving private industry, university, and other Federal laboratories with the Department of Energy-Headquarters (DOE-HQ) Office of Technology Development (OTD) BWIDs Research, Development, Demonstration, Testing, and Evaluation (RDDT\&E) environmental remediation or waste management technology activities. BWID RDDT\&E activities directly interface with remediation efforts of private industry, universities, and other Federal laboratories.

- Adopting successfully-demonstrated technologics throughout the DOE complex.

- Transferring demonstrated technologies and knowledge from the DOE Complex to interested industrial, university, Federal, State and local government, and international users. This is accomplished primarily by publishing technical reports.

\subsection{BWID Technology Scope}

The comprehensive remediation system developed by the BWID will include technologies for the entire remediation cyc le (cradle-to-grave). Specifically, BWID addresses the following technology capabilities:

- Site and waste characterization

- Retrieval

- Treatment (including pre-treatment)

- Analysis and evaluation

- Packaging, transportation, storage, and disposal.

\subsection{BWID Needs}

The BWID program is needs-driven. BWID is supporting an INEL Systems Analysis. The results of this analysis, akong with DOE's nationwide buried waste assessment, will be used to guide the evaluation and demonstration of proposed remeration technologies. 
Preliminary assessments performed throughout the DOE Complex by OTD and the Office of Environmental Restoration (ER) have identified technology deficiencies in several areas of the ER baseline programs. Technology development is required to address the ER baseline deficiencies, the deficiencies identified in EGG-WTD-9594, Systems Design Study Assessment Report, and to assist in the design of a comprehensive cradle-to-grave remediation system that is in compliance with all regulatory requirements.

The technical deficiencies identified in the ER baseline programs are identified in at Appendix D.

\subsection{Responsibilities}

Program guidance for BWID is directed from OTD through the Department of Energy Field Office, Idaho, (DOE-ID) Technical Program Officer (TPO) and the contractor Technical Program Manager (TPM) to the Integrated Demonstration Coordinator (IDC). The IDC coordinates technology transfer issues with industry, universities, and other DOE laboratories and Federal agencies. The EG\&G Idaho, Inc., Office of Research and Technology Applications (ORTA) services are used when determined by the IDC. Figure 3 illustrates these various management relationships.

\subsubsection{Office of Technology Development (OTD)}

The formal roles and responsibilities of OTD include program planning and budgeting, development, management, and evaluation. These responsibilities include development of program policies, strategy, resource justification, and management. DOE-HQ leads a program stecring committee, approves cooperative research and developments in special circumstances, performs external interfaces with other agencies, industry, universities, and international industry and agencies; performs internal interfaces to other DOE offices, provides problem resolution, and develops frameworks for regulatory linkages and public participation aspects of the Integrated Demonstrations and in particular BWID. Finally, DOE-HQ reviews and approves all Technical Task Plans (TTPs), documents of accountability for performance, schedule, milestones, and allocated funds for technical activities to be accomplished, which are proposed by the laboratories.

\subsubsection{Technical Program Officer (TPO)}

DOE Field Offices exercise day-to-day management of RDDT\&E activities. DOE-ID has appointed a TPO to serve as the primary contact between the Field Oflice and OTD. The TPO is responsible for the administrative coordination and implementation of the technology development program and exercises line management authority over BWID. 


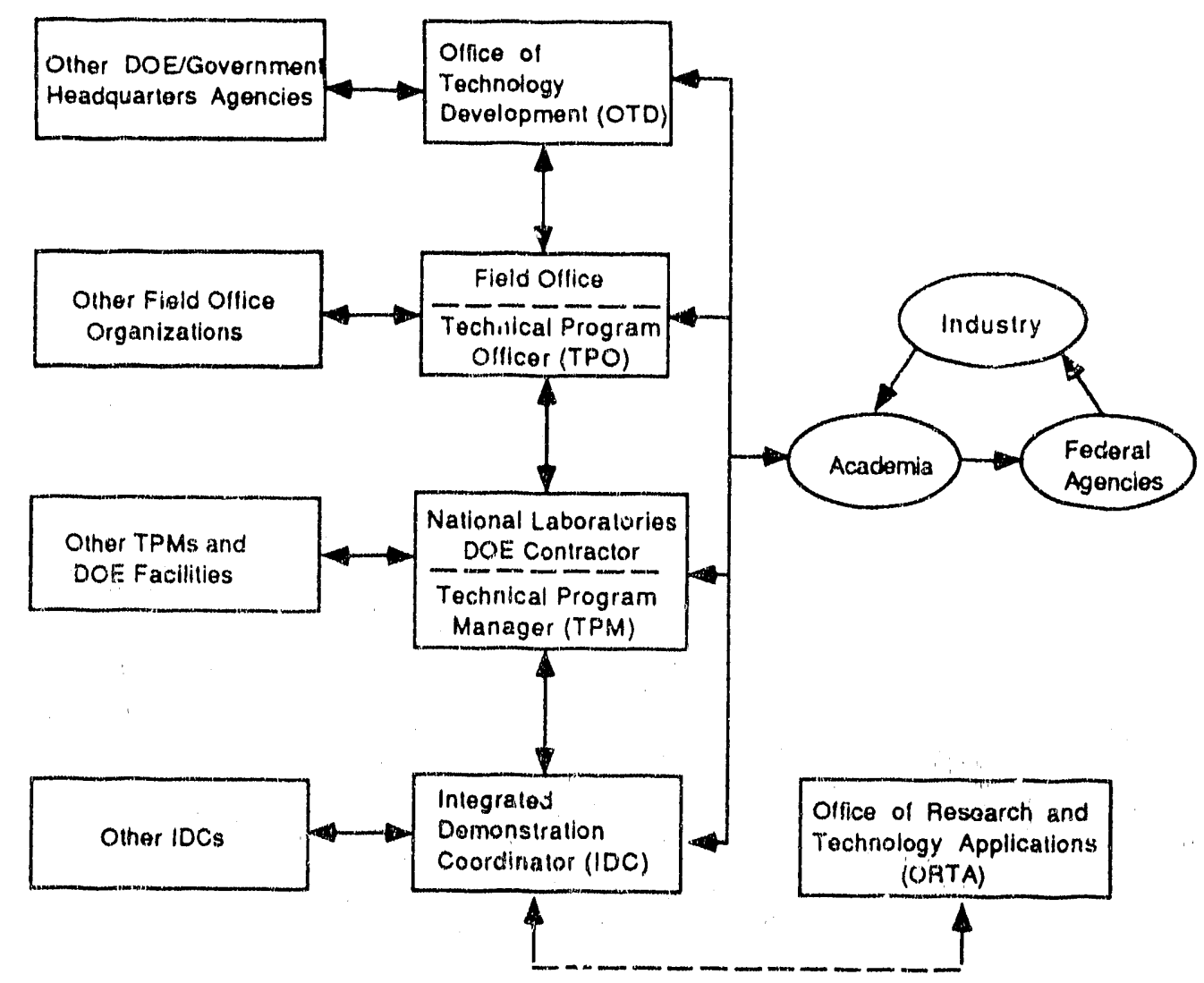

Figure 3. Technology integration management relationships.

\subsubsection{Technical Program Manager (TPM)}

The TPM is responsible for ensuring that all approved TTPs that support BWID are consistent with the directives and guidance provided by the Technical Program Officer and the Integrated Demonstration Coordinator (IDC). The TPM interfaces directly with the IDC for BWID activities. The TPM is responsible for maintaining line management accountability to ensure the activities and tasks defined in the approved TTPs meet all BWID requirements.

The TPM is also responsible for administrative oversight including, but not limited to

- Coordination and oversight of OTD documentation requirements

- Overall task cost/schedule control monitoring and consolidated reporting

- Needs identification and coordination not considered an integral part of a specific task

- Internal and external demonstration coordination not considered integral to a specific task

- Evaluation and implementation of Environmental, Safety, and Health (ES\&H) compliance requirements not considered an integral part of a specific task 
- Coordination and submission of technical review teams, proposal evaluation

- Coordination and collaboration with other sites, the Office of Environmental Restoration and Waste Management (EM), the TPO, and private industry.

\subsubsection{BWID Integrated Demonstration Coordinator (IDC)}

The IDC is responsible for field implementation of the Buried Waste Integrated Demonstration. The IDC integrates technologies for testing and evaluation and directs/coordinates technology transfer issues with industry, universities, and other DOE laboratories and Federal agencies. The IDC is the primary external technolngy integration interface with the private sector, DOE laboratories, and Federal agencies and the internal coordinator for the various OTD offices and DOE personnel involved with the BWID.

The BWID IDC manages, evaluates, and directs technology integration and transfer servires required by BWID, such as those provided by the Technology Integration Group of the EG\&G Idaho Waste Technology Development Department and the Office of Research and Technology Applications (ORTA). This is normally executed through the IDC's technology integration staff:

\subsubsection{Office of Research and Technology Applications (ORTA)}

Transfer of laboratory-developed technology to the private sector may be coordinated by the IDC through ORTA, which is operated by DOE-ID's prime contractor, EG\&G Idaho, Inc. ORTA performs the following functions:

- Provides service support to the BWID Program

- Provides a central coordination point in the Idaho National Engineering Laboratory (INEL) for technology transfer from BWID

- Licenses patents and software to industry as appropriate

- Facilitates one-on-one interactions between the laboratory's scientific personnel and technology recipients for technology transfer from BWID

- Provides and disseminates information on BWID laboratory technology having potential application to private industry or to state or local governments.

\subsection{Relationship to other Plans and Documents}

A brief description of the plans and other documents that provide guidance on the OTD, EM, and DOE-HQ's Technology Integration Program (TIP) are at Appendix C. 


\section{BURIED WASTE INTEGRATED DEMONSTRATION}

\subsection{The Integrated Demonstration}

The Integrated Demonstration (ID) is a management concept developed to facilitate timely and effective application of new and enhanced technologics to meet the DOE's environmental restoration needs. An integrated approach best utilizes goverrment funding and talent by minimizing duplication of effort and assuring rapid evaluation of new technologies. Multiple technologies are assembled and evaluated individually and as part of a complete system as tools for a cradle-to-grave solution to a specific problem representing a generic environmental issue.

Entire systems of technologies are evaluated in the Integrated Demonstration approach with respect to performance, safety, and cost effectiveness. Through collaborative partnerships with DOE laboratories, universities, Federal agencies, and private industries, the developers of each technology interface with experts in the many facets of the demonstration. Major savings in time and Federal tax dollars can be realized by demonstrating multiple technologies at one test bed. Site characterization, modeling, and monitoring infor ation can be shared, validated, and compared, thereby increasing its technical and interpretive value and improving the evaluation of the technologies being demonstrated.

This Integrated Demonstration approach is especially efficient at the environmental sites controlled by DOE, where long-ter m demonstrations of new remediation technologies are planned. This is because the ID approach allows for quick application of potential remediation technologies and provides consistent aitu relevant comparisons of their performance. For the difficult cnvironmental remediation problems where no proven methods exist, new solutions may be proposed and demonstrated. The Integrated Demonstration process includes the ability to exploit successful technologies while abandoning less promising ones.

\subsection{The Buried Waste Integrated Demonstration}

Because of the similarity of the buried waste throughout the DOE Complex and the high cost of remediation, OTD has initiated the BWID at the INEL.

BWID is an extensive research program designed to develop and demonstrate advanced technology systems for remediating buried wastes throughout the DOE Complex. Sites selected within the TRU-contaminated pits and trenches of the INEL's SDA will provide a testing ground for these technologies. Every effort will be made to ensure the waste and site characteristics of the candidate demonstration sites will be representative of the remaining buried waste within the SDA and other buried waste sites within the DOE Complex. This will facilitate the deployment of demonstrated technologies to solve other DOE-wide buried waste needs.

\subsection{Alternatives}

Alternative courses of action to the Integrated Demonstration approach for the BWID include

- no action 
- remediation utilizing conventional technologies and storage

- non-consolidation technology development.

The "no action" alternative is inconsistent with DOE policy relative to the protection of the environment and the health and safety of the public. Remediation of the DOE Complex utilizing conventional technologies is estimated to eost between $\$ 40$ and $\$ 150$ billion. Furthermore, operational technologies do not currently exist for the comprehensive treatment of mixed and TRU wastes. Nonconsolidated technology development, while possibly advancing the state of remediation technologies, will result in inefficient operations and duplication of effort.

\subsection{Anticipated Benefits}

The BWID represents a synergistic effort, pooling the resources of the entire DOE system and inco porating other government agencies, universities, and industry toward meeting a common objective. The major benefit of the approach is the product, a "capability" to solve an environmental problem. A mutually supporting goal is to work with the private sector and provide beneficial conditions that promote cooperation. This includes providing attractive intellectual property provisions that allow private firms to participate with DOE in its environmental activities while minimizing risk, without losing rights to their intellectual property. An important benefit is that this approach encourages industry to commercialize lechnologies developed through partnerships with DOE.

Consolidating technical and financial resources toward a common objective will provide the DOE with the most cost effective and expedient method for remediating DOE buried waste. The pooling of technical expertise should accelerate technological advancements, greatly reduce duplication of efforts, and create major savings in time and Federal tax dollars. 


\section{TECHNOLOGY INTEGRATION}

Technology integration, which includes technology transfer, moves the products from the applied research phase to the implementation phase. Technology integration also facilitates the movement of new technology and development from one application to another. Promoting acceptance of a new technology by users is one area where technology integration operates; promotion of acceptance by the public and regulators is another area. Promotion, however, is not the only direction of information transfer: public concerns are also incorporated into the technology integration process.

The Technology Integration Group of the EG\&G Idaho Waste Technology Development Department will assist the BWID IDC to coordinate the integration of selected technologies between public and private sectors for BWID. This integration will encourage the transfer of trinnologies and information among Federal agencies, private industries, universities, and the international community.

\subsection{Assumptions}

BWID technology integration planning includes the following assumptions:

- Technology transfer is a key element to the success of the BWID

- Funding will be available to support BWID technology transfer activities

- Technologies exist in industry or academia that may be applied to satisfy some of the BWID needs

- BWID will benefit as DOE expands its Office of Environmental Restoration and Waste Management (EM) technology base with cutting-edge research and development (R\&D) from industry, university, and other governmental agencies

- Joint DOE-industry/academia partnerships will result in technology development that applies to the BWID and other integrated demonstrations

- Industrial partners will win as they gain a competitive market edge to commercialize emerging technologies successfully evaluated in the BWID

- Academic partners and other researchers can advance their R\&D with BWID test results

- International marketplace technologies are available to meet some of the BWID needs.

\subsection{Technology Integration Components}

The DOE Office of Technology Development's Technology Integration Branch FY 1992 Technology Integration Programs Plan (Draft) identifies three separate components of Technology Integration as they relate to Integrated Demonstrations: technology infusion, technology adoption, 
and technology diffusion. In an effort to establish consistency within the DOE'system, BWID has also adopted these components of technology integration into its program.

Each component of the technology integration mission is equally important. Over the long term, however, demands of the cleanup eflort will cause shifts in mission emphasis as the life cycle of technology development moves from research through development to demonstration. This is summarized in Table 1.

Table 1. Major milestones for Long-Range Technology Integration Programs.

Ycars

1991

The Integrated Demonstration (ID) concept is developed to the point that activities for sbtaining extern..l technologies for demonstration are needed. The Technolugy Integration Programs and environmental R\&D are locused on meeting ID technology needs.

1991 Technology Integration Programs are established to include technology infusion, technology adoption, and technology diffusion capabilities.

$1991-1997$ Technology infusion from industry, other agencies, universities, and apprepriate international sources.

1995 - 2000 Technology adoption and diffusion.

Prerfominately technology diffusion activitics.

2005 OTD completes contribution to DOE clean-up effort.

2005 - 2019 Ongoing Technology Integration Programs serve the Office of Environmental Restoration (ER) and the Office of Waste Operations (WO) in traditional technology transter capacity.

EM environmental clean-up goal is complete; trarsition to maintenance and monitoring effort.

Source: Long-Range Plan for Technology Integration Programs, Office of Technology Development, May 1991, p. 26.

During 1991, DOE focused its efforts on developing the ID concept and established management teams for the lirst of these demonstrations.

From the latter part of 1991 through 1997, the Technology Integration Programs' seope of emphasis will be on technology infusion initiatives to facilitate the search for and acquisition of technologies from industry, universitics, and other grovernmental agencies to be evaluated in DOE's Integraled Demonstrations.

As 1995 approaches, technologies solicited from sourees external to DOE: in 1991 through 1994 will be tested in focused Integrated Demonstrations. 
With this shift in emphasis, the Technology Integration Program will focus its effort more closely on technology-adoption, coordination-type initiatives followed closely by technology diffusion. Technologies suceessfully demonstrated in the BWID will be ready for diffusion to industry, universities, and other Federal agencies during the period 1995 - 2001. The BWID/DOE will promote these activities through cost-sharing arrangements, the licensing of technology and software, and consulting arrangements by which BWID/INEL laboratory personnel can work with industry and universities. DOE will also provide business assistance services, as necessary, and has established intellectual property provisions to protect ID-generated proprietary and commercially-valuable information.

Additional information concerning the Technology Integration Program long-range concept of operation activities spanning 1995 through 2019 can be found in Long-Range Plan for Technology Integration Programs, Office of Technology Development, May 1991, pages 25 and 26.

\subsubsection{Technology Transfer into the BWID}

Technology infusion is the process by which knowledge and technology from private industry, universities, Federal, and specific international agencies is introduced into the BWID and other lntegrated Demonstrations. The infusion process includes the solicitation, identification, prescreening, screening, and procurement of technologies owned by these entities prior to their demonstration at the BWID.

Integrated Demonstrations, such as BWID, offer a unique opportunity for the private sector. Because of the need to acquire, test, and demonstrate technologies, BWID can be used to cvaluate environmental management companies' technologies for cleaning up buried waste.

4.2.1.1 Infusion Process Description. Based on preliminary assessments perlormed throughout the DOE Complex by Office of Technology Development and the Office of Environmental Restoration (ER). BWID technology deficiencics have been identified in several areas of the ER bascline programs (see Appendix D). Technology development is required to fill voids in waste and site characterization, retrieval and monitoring, treatment and stabilization, regulatory coordination, assessment evaluation, and packaging, transportation, storage, and disposal. The BWID should complete the development of a comprehiensive cradle-to-grave remediation systems for buried waste.

The BWID Integrated Demonstration Coordinator (IDC) will inform ORTA of the BWID needs which may be satisfied either entirely by industry or through a concerted DOE laboratory and private industry cooperative effort. BWID needs may also be publicized through the use of Commerce Business Daily (CBD) announcements and other standard contracting procedures or addressed directly through the use of subcontracts where appropriate. The BWID IDC may also deal directly with the private sector through one-on-one sessions, workshops, and conferences. While the BWID IDC will lead the effort to identify needs, ORTA, in cooperation with the BWID IDC, will identify industry capabilities relative to BWID needs.

Unsolicited proposals received from industry, universities, and other Federal agencies are also evaluated to address BWID needs. If the unsolicited technology/technical knowledge is not required by the BWID, the BWID IDC will notify the Technology Integration Group of the EG\&G Idaho 
Waste Technology Development Department. The Technology Integration Group will coordinate with other DOE sites to determine the need for the unsolicited technology. The Technology Integration Group will also coordinate with ORTA who will inform the Federal Laboratory Consortium (FLC) of the available technology. The FLC serves as a clearinghouse to network the Federal laboratories. It also provides an initial interface for the private sector to identify technologies and technology contacts at Federal laboratories.

If the technology is required and ready for use in the BWID Program, the BWID IDC will initiate action to enter negotiations with the proposer to conclude a subcontract. If the technology must still be developed, the BWID IDC may refer the proposer to ORTA or the DOE Field Office or its representatives to identify private or governmental capital and manpower resources to develop the proposal for possible final acceptance into the BWID Program.

Transfer of knowledge and/or technology possibilities are evaluated jointly on a case-by-case basis between DOE and its represertatives and private industries, universities, and other Federal agencies to determine the technology transter mechanism(s) that will best serve the interests of all partics. Upon final agreement, the technology development process procecds.

4.2.1.2 Technology Transfer Mechanisms. Several mechanisms are available to bring technologies into BWID. Each method has significant advantages and disadvantages to both DOE and the technology proposer. As each method can be modified on a case-by-case basis, this document only generalizes the basic concepts of each mechanism.

A general description of each mechanism is included in Appendix A. Additional information can be obtained from the Points of Contact and the Primary Points of Contact Matrix in Appendix B.

Technology infusion mechanism: include, but are not limited to:

Consortium Agreement

Consulting Arrangements

Contracting and Collaborative Arrangements

Blanket Order Agreement ( $\mathrm{BOA}$ )

Invitation for Bid (IFB)

Request for Proposals (RFP)

Commerce Business Daily Announcements (CBD)

Subcontracts

Unsclicited Proposals

Cost-Sharing Agreements

Federal Laboratory Consortium (FLC)

Grants and Cooperative Agreements

Industrial Interactions

Liatison to the Business Sector

Memorandum of Understanding (MOU)

Program Opportunity Notice (PON)

Program Rescarch and Development Announcericent (PRDA)

Rcimbursable Work for Industry

Rescarch Opportunity Announcernents (ROA) 
Scientilic User Facilities

Small Business Innovation Research Programs

Technical Documents and Software

Technical Personnel Exchange Assignments

University Interactions

Workshops and Conferences

Figure 4 illustrates the infusion process.

\subsubsection{Sharing of Technology within the DOE Complex}

Technology adoption is the process by which knowledge and technology is developed and/or demonstrated and shared within the DOE Complex by the BWID and other Integrated Demonstrations. This process also involves modification of a technology that has been suecessfully demonstrated at one DOE site to meet a need at another DOE site.

Technology transfer is an advantageous process for DOE in that needed and tested technologies can be easily transferred within the DOE Complex. These technologies can be adapted to meet differing requirements in varying environments. Also, basic development and testing costs have been satisfied and there is no payment of royalties nor are the:e negotiations to be conducted concerning patenis and copyrights or with licensing issues.

4.2.2.1 Adoption Process Description. Specific adoption processes and procedures are being addressed by the Office of Technology Development (OTD) Technology Integration Branch. As processes are tested and approved they will be incorporated into OTD's Technology Integration Programs and into this document. The adoption process is planned to be implemented in 1995. Additional information can be found in the Long-Range Plan for Technology Integration Programs, Oftice of Technology Development, May 1991, and in A Guide to Working with the Department of Energy's Office of Technology Development (Draft), November 1991.

4.2.2.2 Technology Transfer Mechanisms. A general description of the following mechanisms are in Appendix A:

Consortium Agreement

Contracting and Collaborative Arrangements

Federal Laboratory Consortium (FLC)

Industrial Interactions

Memorandum of Understanding

Technical Documents anci Soltware

Workshops and Conferences

Figure 5 illustrates the adoption process.

\subsubsection{Transfer of Demonstrated Technology out of the BWID}

Technology diffusion involves the transfer of suceessfully demonstrated innovative technological systems out of the DOE Complex io private industries, universities, Federal agencies, and other 


\section{TECHNOLOGY TRANSFER INTO BWID (Infusion)}

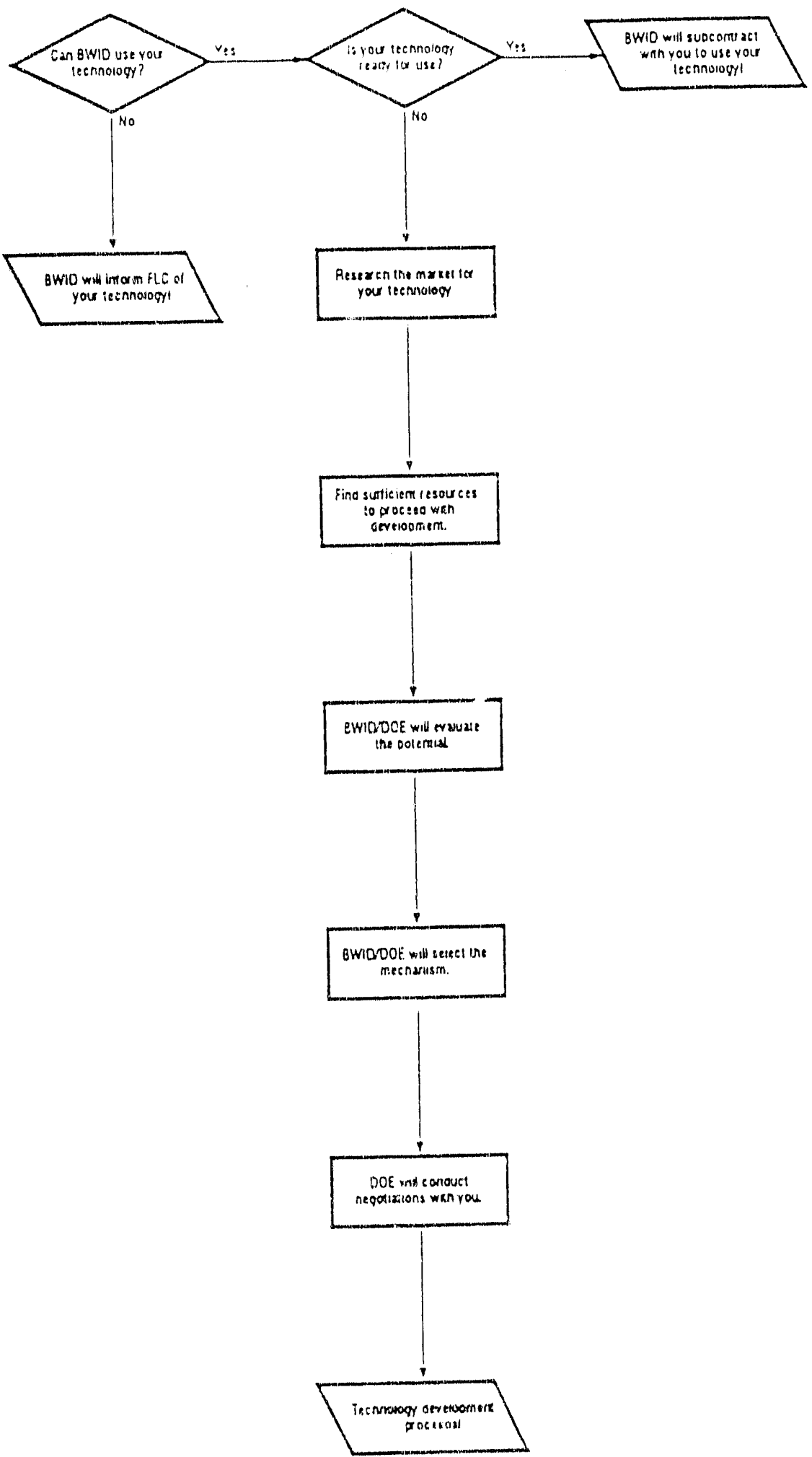

Figure 4. Infusion llow charl. 
TECHNOLOGY TRANSFER BETWEEN BWID AND OTHER DOE SITES (Adoption)

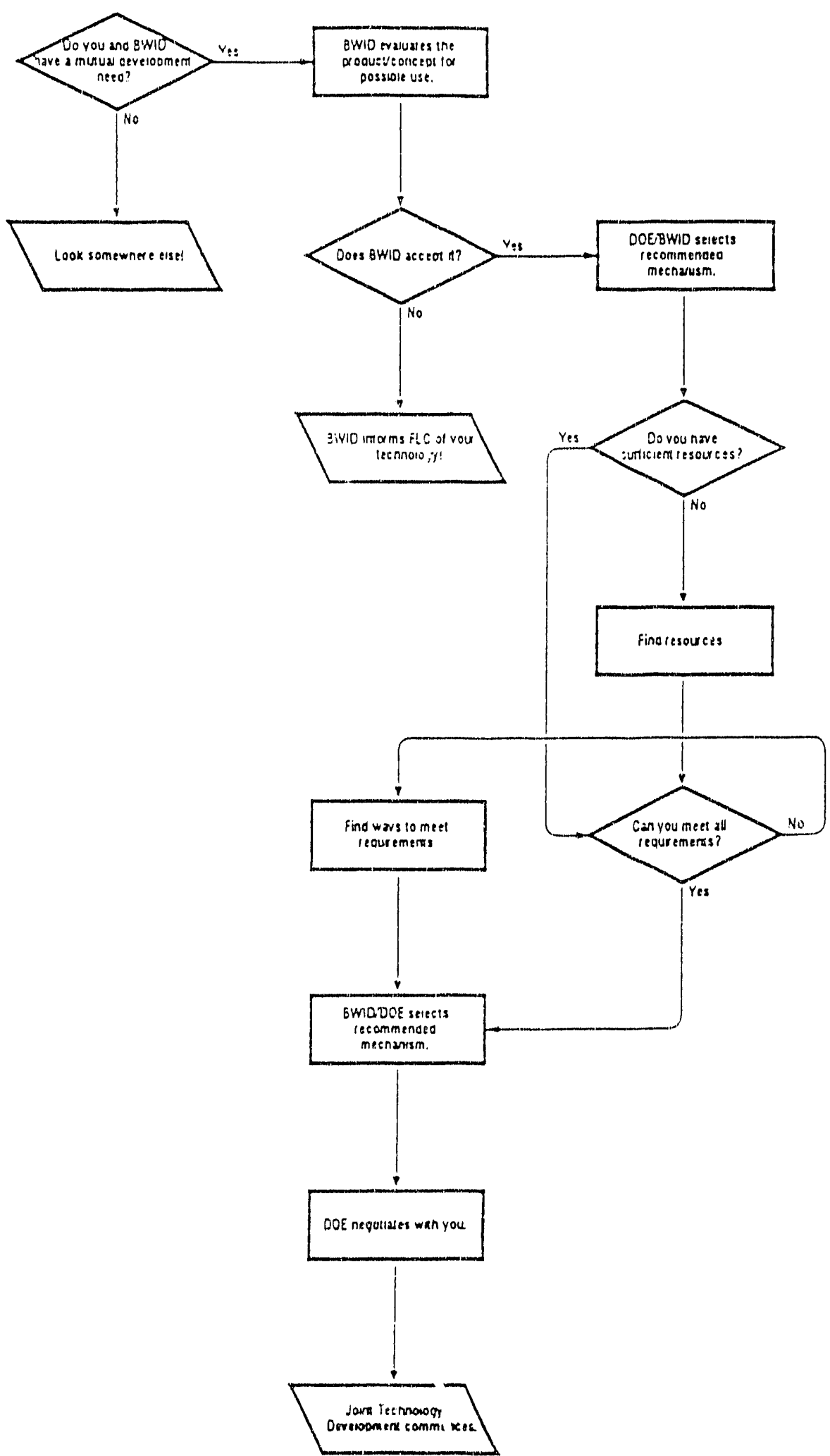

Figure 5. Adoption flow chart. 
interested parties. Technology diflusion also encompasses transferring suceessfully demonstrated technokgy systems to satisfy Office of Environmental Restoration and Waste Management (EM-30) and EM-40) requirements. These parties will then develop the technologies further to meet similar national environmental needs.

4.2.3.1 Process Description. BWID will transfer proven technologics to the various DOE Complex siles with buried waste problems, to private industry, and to universities. Industrial, academic, and DOE participation is encouraged to enhance multidirectional technology transfer.

When soliciting interest in laboratory-developed R\&D capabilities, it is important to provide prospective non-DOE parties as nuch detail as possible. DOE requires equal acess to DOEdeveloped technology in the interest of promoting partnerships with parties having bona fide interests or capabilities. DOE and its representatives provide the widest possible distribution of information regarding opportunities for collaboration in broad lickds of technology. This must be done as rapidly as possible so involved industries will be able to take advantage of time-dependent market opportunities for commercial development. ORTA will cooperate with BWID to solicit interest outside DOE.

Interested partics should initially contact either the BWID IDC or ORTA, EG\&G ldaho, Inc., for information on BWID tested knowledge or technology. The FLC may be contacted for information or contacts within Federal laboratories when specific contacts or location of technologies is nut known. If the requested technology is available from BWID, ORTA will research whether the technology has been patented or is intellectual property. If a patent or a copyright is required, ORTA will coordinate action within EG\&G Idaho, Inc., and with DOE to obtain the patent or copyright.

ORTA will then coordinate with the requestor to determine if the requestor has sufficient resoures and capability to develop the echnology. If additional resources or capabilities are required, ORTA or DOE may suggest possible partners, sources of resources, transfer mechanisms, and so forth, to reduce the business risk, and to propose various alternatives to sharing, disposing, or transferring intellectual property, licensing, and royalties.

ORTA, in coordination with the BWID IDC and DOE, will lormalize the INEL proposal, coordinate the linal negotiations, and determine the technology transfer mechanism.

4.2.3.2 Technology Transter Mechanisms. Several mechanisms are also available to transfer technology out of BWID). Each of the methods has signilicant advantages and disadvantages to DOF and the technolegy proposer/potential use and as cach method can be modilied on a caseby-case basis, this document only gencralizes the basic concepts of each mechanism. A general description of each mechanism is at Appendix A. Additional informaleon can be obtaned from the Points of Conlact and the Primary Points of Contact Matrix identified in Appendix $B$.

Technology diflusion mechanisms include, but are not limited to:

Consortium Agrcement

Consulting Arrangements

Contracting and Collaborative Arrangements

Cooperative Research and Development Agreement (CRADA) 
Cost-Sharing Agreements

Federal Laboratory Consortium (FLC)

Grants and Cooperative Agreements

Industrial Interactions

Interaction and Collaboration with States

Liaison to the Business Sector

Licenses

Memorandum of Understanding (MOU)

Program Opportunity Notices (PON)

Reimbursable Work for Industry

Scientific User Facilities

Small Business Innovation Research Programs (SBIR)

Technical Documents and Software

Technical Personnel Exchangs: Assignments

University Interactions

Workshops and Conferences

Figure 6 illustrates the diffusion process. 


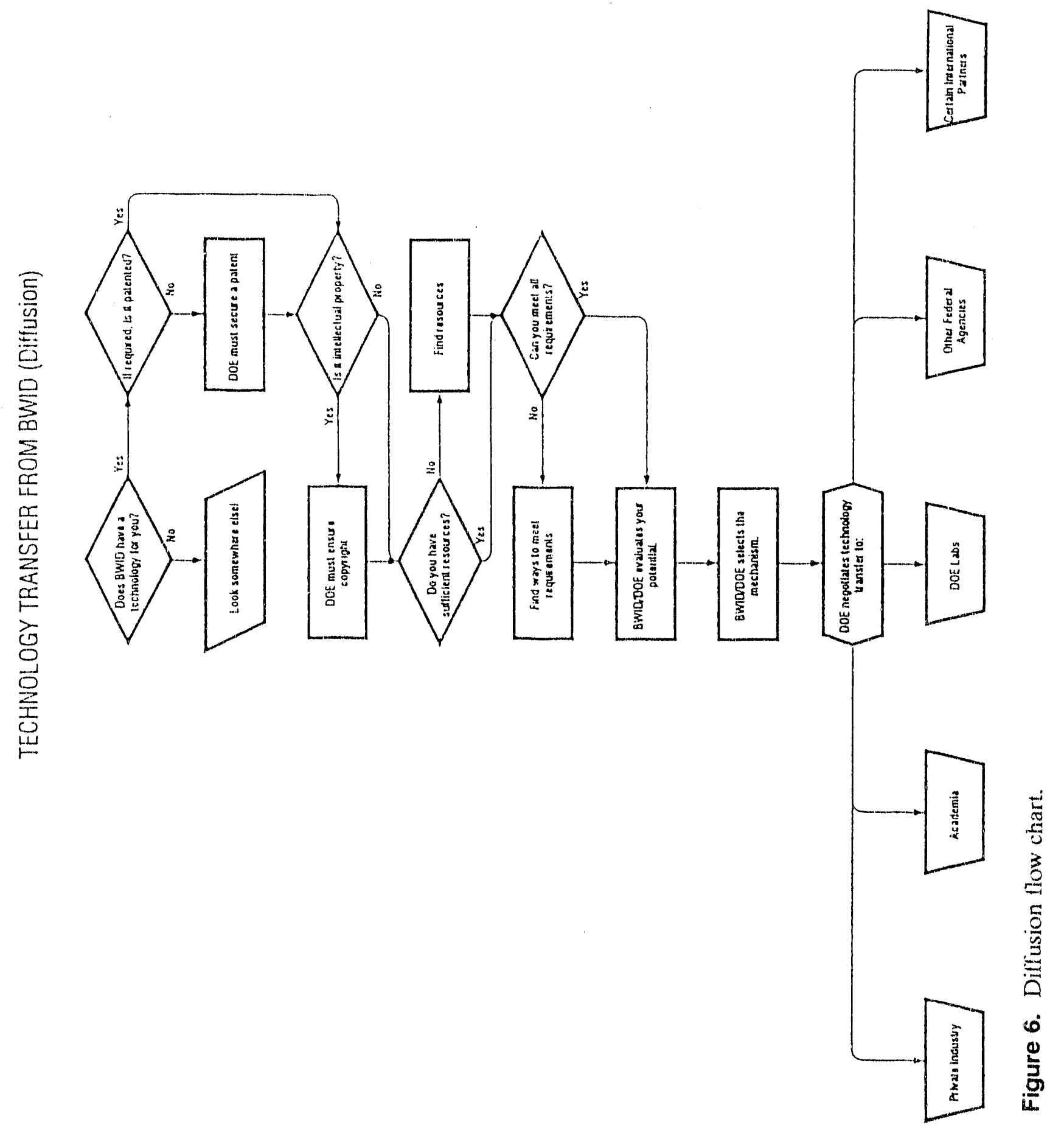




\section{INTELLECTUAL PROPERTY ${ }^{a}$}

Intellectual property is an intangible right that can be licensed, leased or rented, or otherwise transferred between parties in much the same way that rights to real property or other personal property can be transferred. Intellectual property may include inventions and patents, copyrights, trade secrets, and trademarks.

The overriding goal is to work with the private sector to provide mutually beneficial conditions that promote cooperation. This includes providing attractive intellectual property provisions that allow private firms to participate with DOE in its environmental restoration activities without losing rights to their intellectual property. This approach encourages ind stry to commercialize technologies developed through partnerships vith DOE.

The transfer of intellectual property rights is an important and often substantial component of the technology transfer process. Intellectual property rights are most often transferred through contracts or licenses. However, if not adequately protected, intellectual property rights may be lost, adversely affecting the ability to transfer and subsequently commercialize technology. DOE's Acquisition Regulation (DEAR) details policies and procedures concerning patents are at 48 CFR 927.3 and technical data and copyrights at 48 CFR 927.4.

\subsection{Inventions and Patents}

Protecting rights to inventions is an important part of each laboratory's technology transfier program. To protect the patentability of an invention, the inventor and others at the laboratory must guard against premature public disclosure. This includes avoiding the rush to publish new, potentially patentable technical results before liting appropriate invention disclosures or patent applications. Although the desires to publish and to patent seem in opposition, with foresight, it is possible to do both. Protecting the ability to patent need not interfere with cooperative research involving others. Disclosures made in eonfidence under nondisclosure agreements do not preclude obtaining a patent. Before any publication, public use, or public disclosure, patent review should be obtained from legal counsel to protect an invention.

It is important to document a concept and all related work to reduce the invention to practice by using a well-maintained technical notebook. A notebook is a convenient place to record ideas, activities, and results. To be of maximum legal value to support a patent application, notebooks should be bound, have sequentially numbered pages, and contain frequent witnessing and dating of the work by two people other than inventors. An important point not to be overlooked is the prompt filing of the patent application with the U.S. Patent Office.

a. Material for this section is from the following documents:

Long-Range Plan for Technology Integration Programs, Office of Technology Development, May 1991.

A Guide to Working with the Department of Energy's Office of Technology Development (Draft), November 1991. 


\subsection{Copyrights}

The government is not precluded from receiving and holding copyrights transferred to it by assignment, bequest, or otherwise. The copyrighted works of Governmentowned, Contractoroperated (GOCO) employeses are generally regarded as works for hire and the copyrights are, therefore, owned by the $G O C O$ employer. DOE approval is required by an Management and Operating (M\&O) contractor to assert copyrights in such works to cinable the GOCO to enforee the copyright and effect licensing, and use thereof for commercialization. In all cases, as a minimum, the government obtains a license for itself and others acting on its behalf for specified purposes.

Transfer of copyright to computer software through licensing is an important part of technology transfer activities. However, to be eflective, licensing of copyrights implies the right to enforec the copyright against infringers. DOE approval is required by an M\&O contractor to assert computer soltware copyrights. The prime contract defines the terms by which the GOCOcontractor enforecs and licenses its copyrights. For computer soltware, certain materials must be furnished to the Energy Science and Technology Software Center (ESTSC) for public availability. The copyrighted software will not be publicly released by ESTSC unless specifically provided for in the agreements.

Other forms of technical data produced at the laboratories may atso be copyrighted with permassizn of DOE in the name of the $\mathrm{M} \& \mathrm{O}$ contractor. These include blueprints, enginecring drawings, and technical manuals. These works are subject to the prime contract terms and conditions affecting licensing and technology transler of copyrightable works.

\subsection{Withholding of Funding Agreement Data}

OTD may withhold from public dissemination to the extent permitted hy law, for a period of up to. three years, agree 10 nondelivery $10 \mathrm{DOE}$, and to cost-shared data from Integrated Demonstrations when OTD determines that it is in the best interests of the program to do so. Other data will be normally disseminated widely, as per statute and DOE policy for R\&D work. Information disclosure issues and their policy ramilicalions are summarized in Table: 2. Table 3 summarizes OTD's approach to addressing public disclosure necds. Tathle 4 summarizes OTD's approach to the protection and limited withholding of Integrated Demonstration information and intellectual property.

In withholding dissemination, no new exemption is added to the Freedom of Information Act since the information witheld is not an agency record because it has not been delivered to the Government. This complies with Section 31, Atomic Energy Ad (AFA), because dissemination of the information is only delayed, not prevented. 


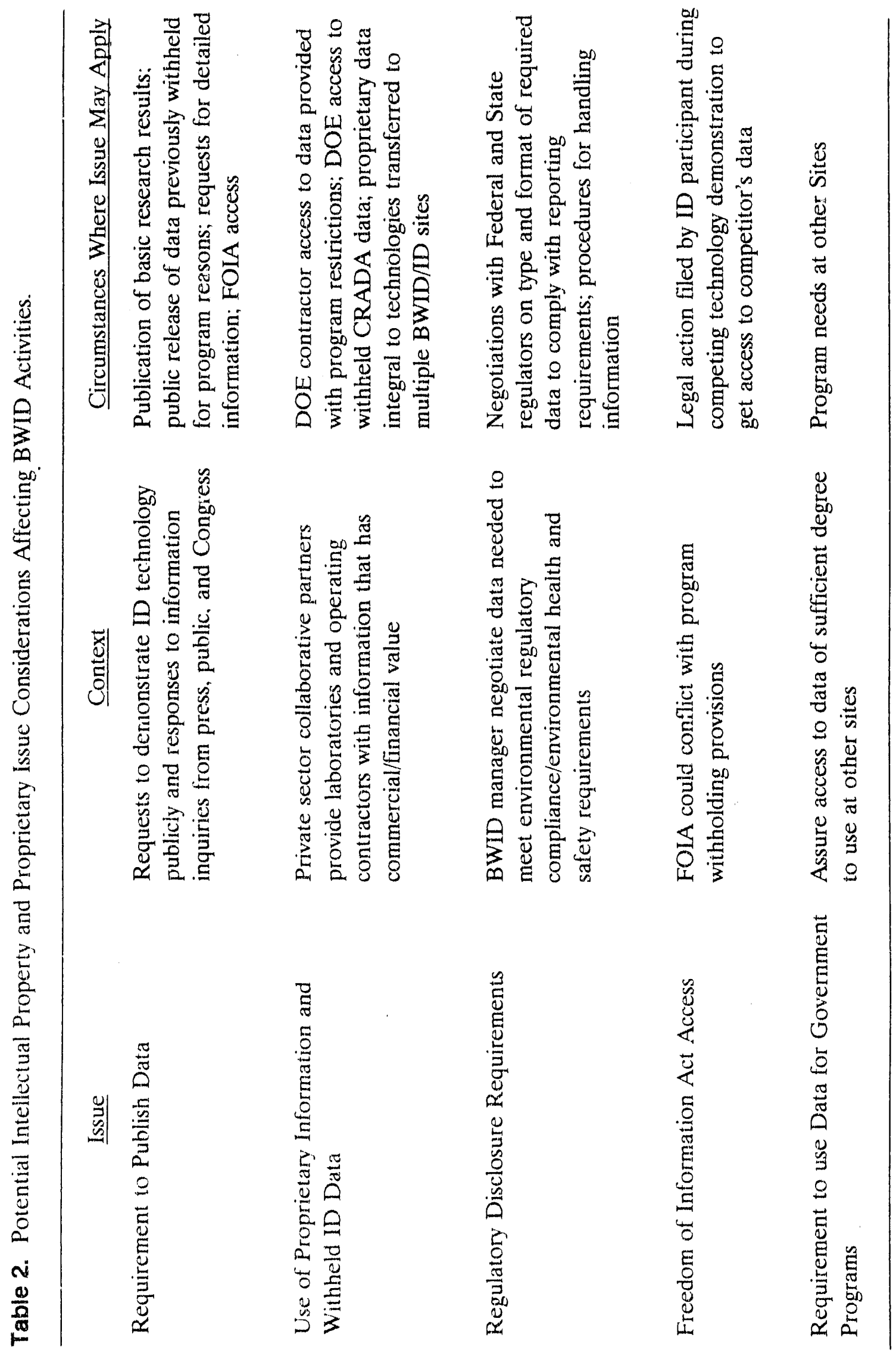




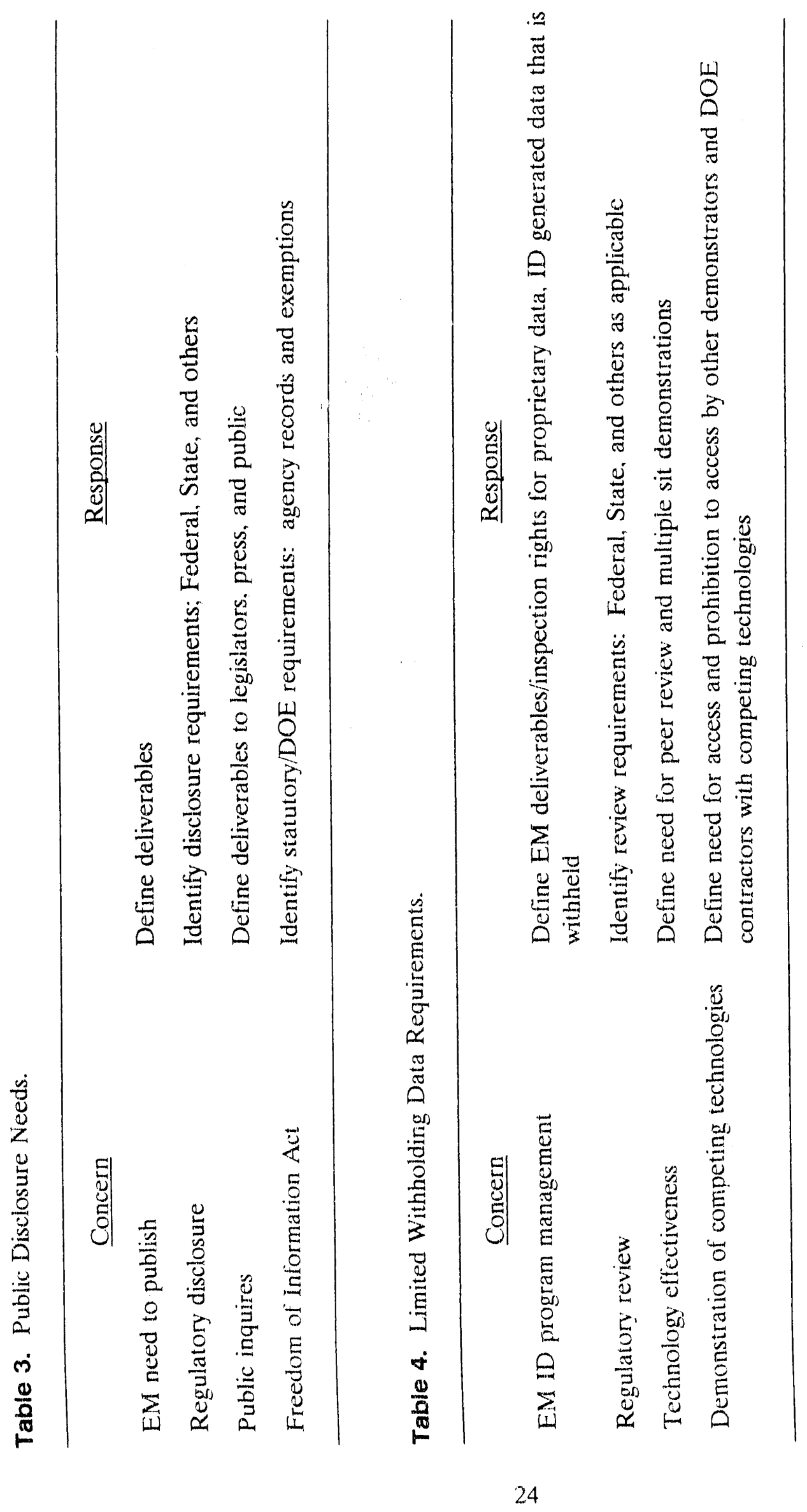


Appendix A

Technology Integration Mechanisms 
A-2 


\section{Appendix A}

\section{Technology Integration Mechanisms}

Transfer of knowledge and/or technology possibilities are evaluated jointly on a case-by-case basis between DOE and its representatives and private industries, universities, other Federal agencies and international agencies/industry to determine the mechanism(s) to best serve the interests of all parties involved. Key elements in the technology transfer process may include the knowledge or technology to be transferred, the capabilities of the parties involved, the technical and financial resources of the parties, and the priority of the technology need.

The mechanisms and their descriptions listed here are subject to change. DOE is in the process of reviewing all contractual possibilities to enhance the transfer of technology. Changes in these mechanisms is a continuing process and each mechanism is adapted to meet the needs of DOE and its contractual participants.

Additional information can be obtained from the Points of Contact and the Primary Points of Contaet Matrix identified in Appendix B.

\section{$\star \quad$ Commerce Business Daily (CBD)}

The CBD is the public notification media by which U.S. Government agencies identify proposed contract actions and awards. The CBD is published in five or six editions weekly, as necessary.

Contracting officers may publish in the $C B D$, advance notices of their interest in potential R\&D programs whenever existing solicitation mailing lists do not include a sufficient number of concerns to obtain adequate competition. Advance notices will enable potential sources to learn of R\&D programs and provide these sources with an opportunity to submit information which will permit evaluation of their capabilities.

\section{$\star$ - Consortium Agrecment}

Consortia allow for multiple partners to participate in a collaborative research effort by providing funds and/or performing in-kind research. The heart of the agreement deals with the sharing of intellectual property rights among the participants.

Consortia will be considered for situations where several companies will be combining their resources to address a common technical problem. Leveraging of funds to implement a consortium can offer a synergism to overall program effectiveness. A provision to provide a 3-year limited protection for data with commercial value resulting from the (Buried Waste) Integrated Demonstrations has been developed to encourage private sector participation in Integrated Demonstrations. 
The consortium agreement is the agreement of choice when there are intellectual property rights considerations among a variely of partners.

\section{$\star$ Consulting Arrangements}

Scientists and engineers at the DOE laboratories are available to consult in their areas of technical expertise. Each laboratory contractor has its own corsulting practices that comply with DOE consulting guidelines. Laboratory staff are generally free to consult for pay, and many laboratories have programs that allow their employees to provide free technical assistance to outside organizations on a limited and selected basis. Laboratory employees who are involved in consulting activities are allowed to sign nondisclosure arrangements.

EG\&G Idaho, Inc, has a Technology Assistance Program which is operated by the EG\&G Idaho, Inc., Office of Research and Technology Applications (ORTA). Assistance provided through this program is tree of charge.

EG\&G Idaho, Inc., employees must complete a Request for Approval of Outside Program before providing an outside consulting service.

\section{* - Contracting and Collaborative Arrangements}

The OTD facilitates the development of subcontracts, grants, R\&D contracts, and cooperative agreements to work collaboratively with industry and universities. Such agreements offer an opportunity for the private sector and universities to be integral in developing new and advanced technology for the OTD technology base.

A major benefit of these agreements is that technology transfer can be automatically integrated into research programs that include cost-sharing by the industrial and university partners. Costsharing can significantly leverage OTD rescarch lunds.

A provision to provide a 3 year limited protection for data with commercial value resulting from the BWID has heen developed to encourage private sector participation in the BWID.

\section{- Cooperative Rescarch and Development Agreement (CRADA)}

CRADAs are agreements between a government-swned, contractor-eperated $(\mathrm{GOCO})$ or a government-owned. govermment-operated (GOGO) R\&D laboratory and any non-Federal agent to perform rescarch in areas of mutual interest and benefit. The partner may provide funds, facilities, equipment, personnel, or other resoures. The $60 \mathrm{CO} / \mathrm{GOGO}$ can provide personnel, resources, and equipment. CRADAs are not grants, procurements, or subcontracts. They are at specialized technology transter $(0)$ provided by Congress. CRADAs allow certain intormation from the conperative rescarch to be protected from discksure for up to five years under the Freedom of Infoumation Act. CRADAs require that no funds leave the laboratory.

CRADAs are intended of unsfer lechnohgy to an industry partner by having the partners rescarchers work with EG\&C Idaho's researchers in a joint effort. 
CRADAs are attractive to industry because the agrecments allow proprictary data or information brought into or developed during a research program to be held confidential for 5 years.

The CRADA, as approved by the DOE Field Office, is the instrument of choice when:

- the partner is an active participant to the research effort

- there is a requirement to designate information as CRADA protected information

- EG\&G Idaho, Inc., rather than the DOF: Field Office, is the desired partner.

\section{$\star$ Cost-Sharing Agreements}

Cost-sharing agreements allow industry partners to contribute financially to research programs in Federal laboratories. Partners receive intellectual rights in return for their financial support.

The cost-sharing agreement is the agreement of choice when the partners contribution is limited to financial support.

\section{- Federal Laboratory Consortium (FLC)}

The FLC is an interagency network of Federal R\&D laboratory representatives that addresses technology transfer issues and methods facilitating increased interactions between U.S. industry and Federal laboratories. Initially, the FLC was an iniormal network that criginated in the 1970s in the Department of Defense. The 1986 amendments to the Sievenson-Wydler Technology Innovation Act formalized the FLC and established that each executive branch R\&D agency provide operating funds annually to the FLC. The DOE laboratories have actively supported the FLC, its projects, and its activities.

The FLC network of federal laboratories can be accessed through six regional coordinators, individual laboratories, and an FLC Clearing-house. The strength of the network is the ability to put the potential user in contact with a federal laboratory person with expertise in a specific area of interest. Once the contact is found, the arrangements for transfer are between the user and the laboratory. The response can take the form of readily available material, technical advice, licensing or collaborative research depending on the situation, resources available, and the policies and procedures of the laboratory.

The FLC network of technology transfer laboratory representatives is most effective when requests identify a specific problem or need and personal contact is required. Topies of interest brokered through this network include new or modified technologies, processes or technical assistance.

\section{* Grantsi and Cooperative Agrecments}

Grants and cooperative agreements are chosen if (in addition to the 30-year clean-up goal of DOE sites) 51 percent or more of the overall value of the effort is related to the pursuit of 
one or more goals involving: possible non-DOE or other Federal agency application and use; advancement of present and future U.S. capabilities in domestic and international environriental remediation markets: technology transfer; advancement of scientific knowledge; promoting education and training of individuals and firms to advance U.S. remediation capabilities; or similar goals in the public interest.

\section{$\star *$ Industrial Interactions}

The DOE and its laboratories use a variety of methods for interacting with private industry. Some of these interactions occur on a program-specific basis through Advisory Committecs that provide guidance in specific research and developmeni areas. Others transactions occur through workshops and conferences sponsored by the laboratories or at the senior management level through efforts such as the Technology Transfer Roundtable convened by Energy Secretary Watkins in March 1990 in conjunction with the development of the National Energy Strategy.

The DOE and its laboratories are also major participants and supporters of the Federal Laboratory Consorium, which is an organization that focuses on facilitating increased interactions between U.S. industry and Federal laboratories.

\section{- Interaction and Collaboration with States}

DOE and its laboratories are seeking additional ways to work with companies of all sizes and with universities. A new networking approach is to collaborate with or work through the State Offices of Economic Development. Collaboration and leveraging of Federal, State, university and industry resources are effective ways to transfer technology, particularly to small businesis.

\section{$\star$ Liaison to the Business Sector}

Individual laboratories, such as the INEL, establish interactions with U.S. industry that include personnel exchanges, co-planning of research programs, collaborative projects, and scientist-toscientist discussions.

\section{- Licenses}

All of the nonprofit laboratory contractors automatically can retain patent titles and license the technoingy in all technical areas except for defense and other sensitive programs. The forprofit laboratory contractors, such as EG\&G Idaho, Inc., have a similar intellectual property ownership capability. EG\&G Idaho, Inc., has received a class waiver and has the first option to retain the patent lor work developed within EG\&G Idaho, Inc. DOE for-profit laboratory contractors presently operate on a case-by-case hasis for patent waivers.

Licensing is used to transler the intellectual property rights of patented invention to industry partners. Licenses may be negotiated in conjunction with a CRADA and other partnership arrangements with industry. 
Licenses should be considered when a patent is held or a patent application is pending on an invention that is related to the technology of interest.

\section{$\star$ Memorandum of Understanding (MOU)}

A MOU is a written agreement broadly stating basic understandings and describing a mechanism for coordinating activities to be engaged in by DOE and other signatory authorities. It is not limited to understandings with Federal agencies but may include: local, State, international, or other governmental entities; the private sector; and educational institutions. A MOU is not considered a binding contract; it cannot be used to obligate or commit funds or as the basis for the transfer of funds from one agency to another. If a commitment, obligation, or transfer of funds is required, a specific interagency agreement shall be developed between DOE and the participating organization.

\section{$\star$ Program Opportunity Notice (PON)}

PONs are used by Federal agencies when the purpose is to accelerate the demonstration of the technical, operational, economic, and commercial feasibility, and the environmental and social acceptability of particular technologies or system. PONs are typically used for cost-shared dernonstrations of technology involving a physical plant; however, they can be used in the demonstration of a process, apparatus, or system as long as commercial application is still a strong consideration.

The PON is the instrument of choice when only a limited amount of adaptive enginecring is needed for demonstration.

\section{Program Research and Development Announcement (PRDA)}

PRDAs are program solicitation acquisition mechanisms used by Federal agencies when there is a diversity of possible $R \& D$ approaches and/or a need for fostering new and creative solutions. PRDAs are typically used when there is a need for a significant amount of applied R\&D work, but can also be used for demonstration, test, and evaluation efforts. These mechanisms, like ROAs, are being used for the Integrated Demonstrations.

\section{$\star$ Rcimbursable Work for Industry}

DOE laboratories are available to perform work for industry or for other Federal agencies as long as the work pertains to the mission of the respective laboratories and does not compete with the private sector. The special technical capabilities and unique lacilities at DOE R\&D laboratories are an incentive for the private sector to use DOE's facilities and entractor expertise $\vdots$ in this reimbursable work for industry mode.

In a reimbursable work for industry agreement, the entire cost of the work performed at EG\&G idaho is borne by the industry partner. Consequenlly, the industry partner usually obtains rights for commercialization of any inventions made during the accomplishment of work under the agreement. An advance class patent waiver gives ownership of any inventions 
resulting from the research to the participating private sector company. Agreement on future commercialization is contained in the reimbursable work for industry agreement or contract and is waived for all technical areas except for delense and other sensitive programs.

\section{Rexearch Opportunity Announcements (ROA)}

ROAs are being used by Federal agencies to stimulate the development of solutions to broad cross-cutting problems to support basic research, general science, and problem solving in multiple areas.

ROAs are being actively explored for the solicitation of new applied research proposals from industry. Although this mechanism cannot replace unsolicited proposals, it will help to provide broad guidance to the private sector for the general areas of interest to DOE for the Buried Waste Integrated Demonstration. The ROA is not used to acquire specilic systems or hardware where other acquisition mechanisms should be used. This mechanism formerly was identified as the Broad Agency Announcement (BAA).

These announcements are typically published in the Federal Register and the Commerce Business Daily (CBD) on an annual basis.

\section{$\star$ Scientific User Facilitics}

Potential user research proposals are peer reviewed for appropriateness and quality before access to a facility is scheduled. Patent rights to any resulting inventions are waived in advance to appropriate users. If the users publish the results of their work, there is no charge to work at the facility; if the work is proprietary, users pay full cost of using the facility.

DOE laboratories represent valuable, often unique, resources for university and industrial scientists. DOE makes its laboratories, including large experimental facilities, available to qualified scientists who can make the best use of these capabilities. The scientific user facilities present collaborative opportunities among industries, universities, and the laboratorics.

\section{- Small Business Innovation Research Programs (SBIR)}

The SBIR, now in its ninth year, continues to strengthen the role that small, innovative firms play in meeting the Nation's research and development needs, and in stimulating technological innovation and commercialization of ideas developed through federally funded research and development. The Department of Energy Office of Environmental Restoration and Waste Management (EM) is developing a SBIR Program in 1992.

There are special opportunities for small businesses to work in the Buried Waste Integrated Demonstration. Opportunities exist through grants, subcontracts, cooperative research and developmental agreements, and personnel assignments.

The federally funded SBIR Program assists and promoles small business participation in government programs. Characteristics of the arrangement are a 2 -year confidentiality limit on data, ability of the contractor to acquire title to inventions, and multiple funding phases from 
feasibility to commercialization. For more information, contact the EG\&G Idaho, Inc., Office of Research and Technology Applications (ORTA) or the DOE SBIR office and refer to 15 USC 638 (United States Code) for the statutory reference.

\section{$\star \quad$ Subcontracts}

A subcontract is a lower-tier contract entered into with a GOCO/GOGO of government prime contractor to provide supplies or services. This may be an effective tool of technology transfer by integrating government or laboratory know-how into the commercial environment. A subcontract may be a cost-shared arrangement.

All subeontracts for research and development are funding agreements under Public Laws 96517 and 98-620 which permit nonprofit organizations and small businesses to obtain title to their inventions. The awarding contractor may not obtain rights to inventions made by subcontractors as a condition for entering into the subcontract.

\section{- Technical Documents and Software}

Technical documents and database software are a traditional means of disseminating information on research results and technologies available at laboratories. Every author of a technical program report written at a DOE laboratory must submit copies of the report to the Office of Scientific and Technical Information (OSTI) in Oak Ridge, Tennessee, as long as the contents of the report are considered to be in the public domain. OSTI also compiles and manages various types of databases and computer software programs to assist individuals in determining the types of technical activities being performed at the laboratories and the technologies that are available.

DOE contractor-operated laboratories license EM-developed technology and sof tware to which they elect to take title. In other situations where DOE owns title to the resultant inventions, the DOE Office of General Counsel does the licensing. DOE can "rent" title of the technology to an external entity wishing to make, sell, or use the technology. Licensing activities are done within existing DOE intellectual property provisions.

\section{Technical Personnel Exchange Assignments}

Personnel exchanges with U.S. industries and universities are an important component of the technology transfer efforts of the DOE. These exchanges may be conducted through specific research and development programs or arranged on an informal basis with the laboratories. In addition, a separate technical personnel exchange program may be conducted with a focus on technology transfer between private sector companies and the laboratories. This program will support travel, living, and other costs for personnel participating in exchanges.

Industry contributes substantial cost-sharing for these exchange assignments; all sizes of companies may participate. To encourage such collaboration, the rights to any resulting patents go to the private sector company. The exchanges, which are expected to run approximately three to six months, are opportunities for the laboratories and industry to develop improved 
relations and are ideal for updating technical skills and for transferring technology and technical knowledge into and out of the Buried Waste Integrated Demonstration.

\section{$\star$ University Interactions}

Research collaboration among university, private sector, and Federal scientists is ongoing in various research and development programs and at laboratory scientific user facilities. Most laboratories have formed collaborative agreements with universities covering staff/faculty exchanges, joint instructional programs, university agreement for joint research, administrative procedures for large-scale scientific computing systems, and joint appointment of affiliate scientists.

\section{$\star$ - Workshops and Conferences}

Sec Industrial Interactions. 
Appendix B

\section{BWID Points of Contact}


B-2.

年 


\section{Appendix B}

\section{BWID Points of Contact}

The following Points of Contacts are current as of the publication of this document. The Points of Contact for each of the technology integration mechanisms listed in Appendix $\mathrm{A}$ are identified in the Primary Points of Contact Matrix at the end of this Appendix.

DOE, Idaho Field Office

Technical Program Officer (TPO)

William N. Fitch

Technology Development and Integration Division

Department of Energy, Idaho Field Office

785 DOE Place

Idaho Falls, ID 83402-1119

(208) $526-4983$

EG\&G Idaho, Inc.

Technical Program Manager (TPM)

Paul Wichlacz

EG\&G Idaho, Inc.

P.O. Box 1625

Idaho Falls, ID 83415.3940

(208) 526-1292

EG\&G Idaho, Inc.

BWID Acting Integrated Demonstration Coordinator (IDC)

S.K. Merrill

EG\&G Idaho, Inc.

P.O. Box 1625

Idaho Falls, ID 83415-3930

(208) 526-(0797

Note: The BWID Program Manager, listed below, is the primary contact for all Technology Integration issues for the BWID Integrated Demonstration Coordinator (IDC). 
EG\&G Idaho, Inc.

BWID Integrated Demonstration Program Manager

Kevin Kostclnik

EG\&G Idaho, Inc.

P.O. Box 1625

Idaho Falls, ID $83415-3970$

(208) 526-9642

EG\&G Idaho,Inc.

Office of Rescarch and Technology Applications (ORTA)

Richard Holman

Idaho National Engineering Laboratory

P.O. Box 1625

ldaho Falls, ID 8.3415-3561

(208) $526-1571$

DOE, ldaho Ficld Office

Contracts Management Division

Jeffery R. Hoyles

Contracts Management Division

Department of Energy, Idaho Field Office

785 DOE Place

Idaho Falls, ID 83402-1221

(208) 526-1478

EG\&G Idaho, Inc.

Procurement Group

For Commerce Business Daily Announcements (CBD)

Bradley W. Trost

EG\&G Idaho, Inc.

P.O. Box 1625

Idaho Falls, ID 83415-2082

(20) 526-0116

For Lnvironmental and Waste Management Acquisitions

Renee Simmons

EG\&G Iditho, Inc.

P.O. Bo) 1625

Idaho Falls, ID 83415-2082

Telephone (208) 526-1661 
For Science and Energy Acquisitions

Craig D. Cutler

EG\&G Idaho, Inc.

P.O. Box 1625

Idaho Falls, ID 83415-2082

Telephone (208) 526-1018

EG\&G Idaho, Inc.

Procurement Group

For Selling to EG\&G Idaho Booklet

Lynn H. Crockett

EG\&G Idaho, Inc.

P.O. Box 1625

Idaho Falls, ID 83415-2082

Telephone (208) 526-1669

\section{Federal Laboratory Consortium}

George Linsteadt

Federal Laboratory Consortium Administrator

P.O. Box 545

Sequim, WA 98382

Telephone (206) 683-1005 


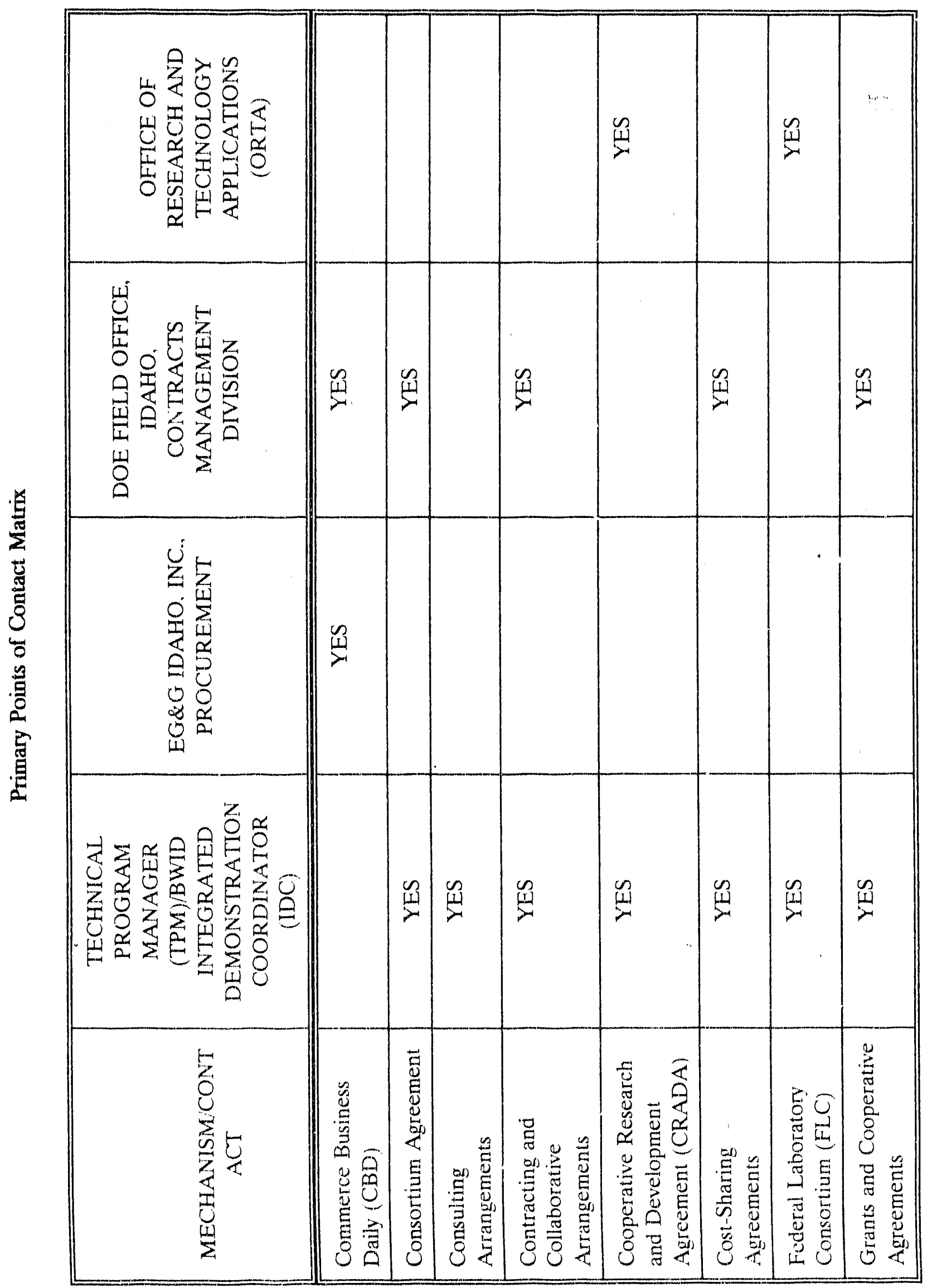




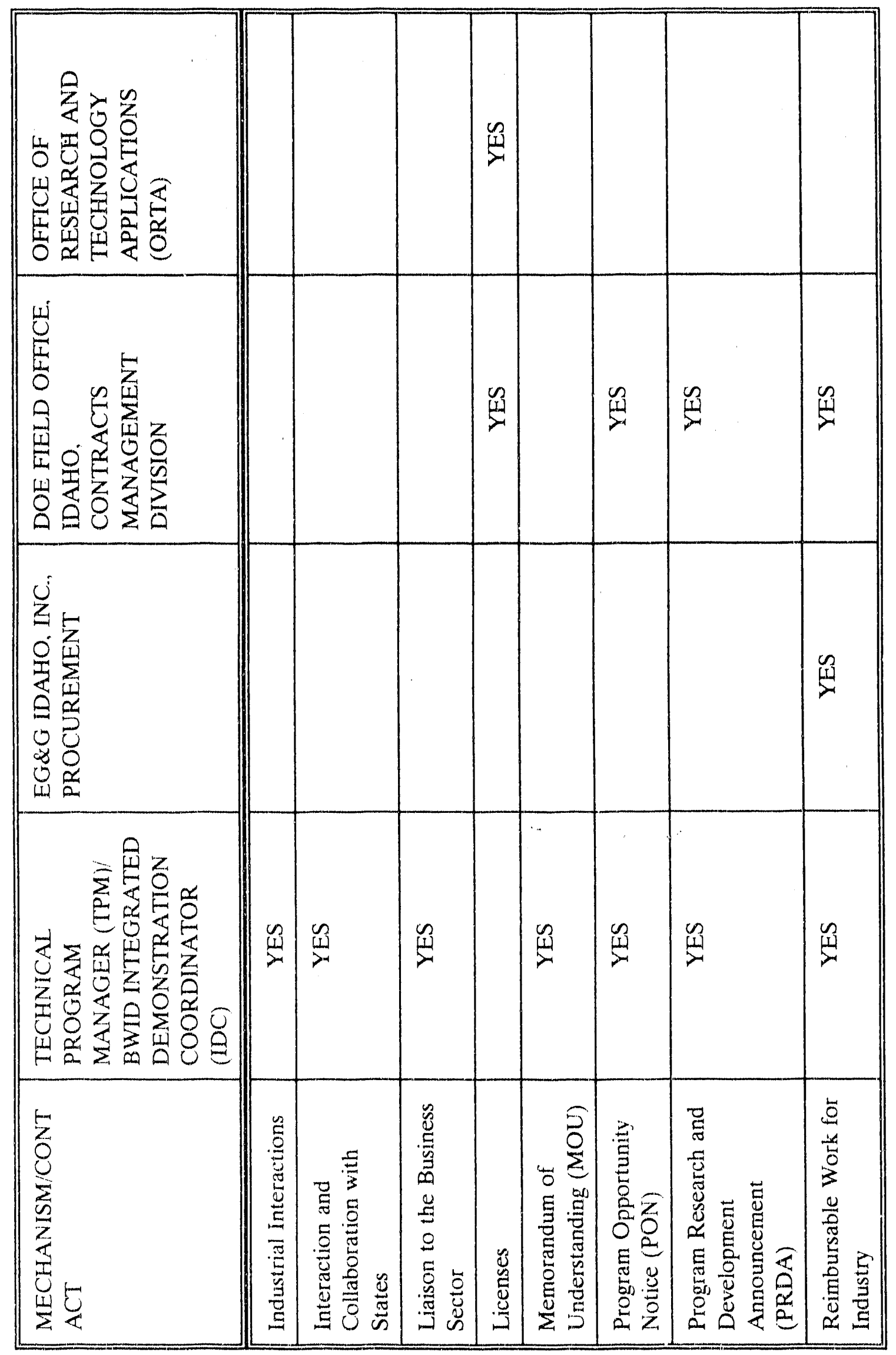

B-7 


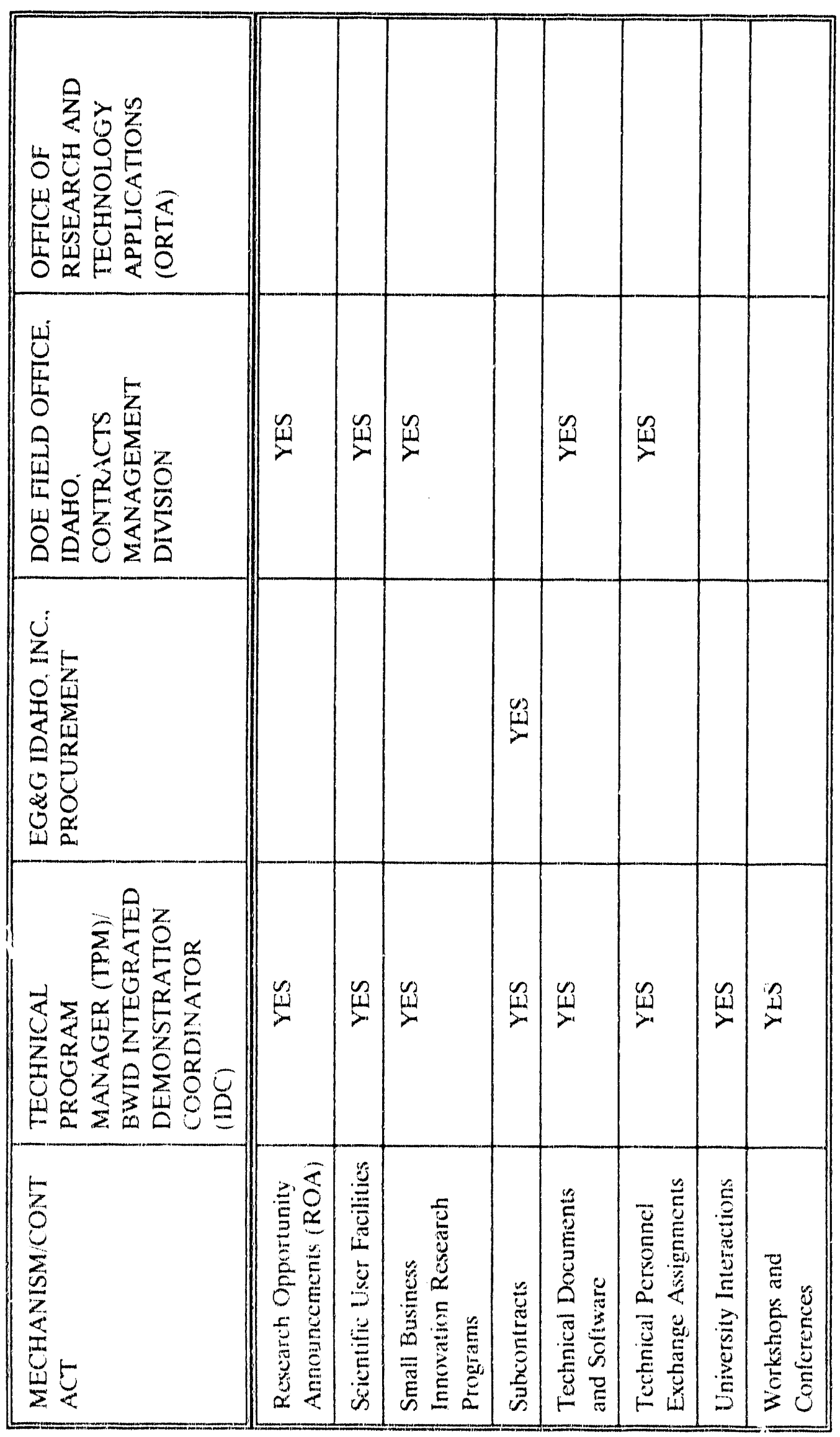

B. 8 
Appendix C

References 
C-2 


\section{Appendix C}

\section{References}

Following is a brief description of the programs and plans that currently provide guidance for the Office of Technology Development, Environmental Restoration and Waste Management (EM), U.S. Department of Energy, technology integration programs. These have been used to develop this Buried Waste Integrated Demonstration Technology Integration Process.

Material from the following references has been used verbatim in this document.

Department of Energy Environmental Restoration and Waste Management Five-Year Plan, Fiscal Years 1993-1997, August 1991. The Five-Year Plan discusses current DOE Environmental Management program accomplishments, what the program intends to accomplish over the next 5 years, and where it needs to be heading in order to meet its 30-year and other environmental góals.

Long-Range Plan for Technology Integration Programs, Office of Technology Development, May 1991. This plan describes the Technology Integration Programs (TIP) supporting the mission of the OTD, within DOE's Office of Environmental Restoration and Waste Management. The Technology Integration Program provides the structure to facilitate applications of innovative environmental technologies through collaborative partnerships with U.S. industry, the National laboratories, other Federal agencies, universities, and appropriate international participants.

Technology Integration Branch FY 1992 Technology Integration Programs Plan (Draft), Office of Technology Development, October 1991. This plan describes Technology Integration Programs missions and activities to be implemented in Fiscal Year 1992 to support the mission of the Office of Technology Development, Environmental Restoration and Waste Management, U.S. Department of Energy. This plan also describes the Technology Integration Programs concept of operations, participant roles and responsibilities, and FY 1992 program implementation activities, program management controls, and planning/evaluation mechanisms.

Technology Integration Branch Fiscal Year 1992 Regulatory Coordination Program Management Program Plan (Draft), Oftice of Technology Development, October 1991. This plan outlines the Technology Integration Programs Regulatory Coordination Program in terms of goals and objectives, as well as actions needed for implementation.

Technology Integration Branch FY 1992 Public Participation Program Management and Implementation Plan (Draft), Office of Technology Development, October 1991. This plan oullines the Technology Integration Programs Public Participation Program goals and objectives, and steps being taken in FY 1992 to move toward those goals and objectives, based on the challenges and opportunities currently recognized or assumed.

Technology Transler: A DOE and Industry Partnership for the Future, January 1991. This handhook describes the philosoplzy and process of ongoing DOE technology transfer efforts. The 
handbook provides an overview of technology transfer and describes the process of making lederally developed science and technology available to users in industry, academia, or state and local government agencies.

A Guide to Working with the Department of Energy's Office of Technology Development (Draft), November 1991. This guide is intended to assist those interested in providing services to or wishing to test and develop technologies with the Office of Technology Development, Environmental Restoration and Waste Management, U.S. Department of Energy.

EGG-WTD-9870) Rev. 1, Intormal Report, Buried Waste Iniegrated Demonstration Plan, Revision 1, December 1991. This document describes the management, operating procedures, programmatic objectives, and schedules for BWID. Technology support functions required to support BWID, such as regulatory coordination, safety analyses, risk evaluations, facility requirements, and data management, are presented.

EGG-WTD-9594, Systems Design Study Assessment Report, July 1991.

Technology '89 Accomplishments in Technology Transfer from DOE and Its Laboratories, U.S. Department of Energy, R\&D Laboratory Technology Transfer Program, January 1991.

Technology ' 90 Accomplishments in Technology Transfer from DOE and Its Laboratories, U.S. Department of Energy, R\&D Laboratory Technology Transfer Program, January 1991.

Selling to EG\&G Idaho. (See Appendix B, BWID Points of Contact, EG\&G Idaho, Inc., Procurement Group to oblain this booklet.) 
Appendix D

\section{BWID Needs}


D-2 


\section{Appendix D}

\section{BWID Needs}

Preliminary assessments performed throughout the DOE complex by the Office of Technology Development and the Environmental Restoration Program (ERP) have identilied technology deficiencies in several areas of the ERP baseline programs. Technology development is required to fill the gaps. EGG-WTD-9870 Rev. 1, Informal Report, Buried Waste Integrated Demonstration Plan has identified several of these gaps, which are presented here to complete the development of comprehensive cradle-to-grave remediation systems.

\section{Site/Waste Characterization}

Most buried waste is highly heterogeneous and contains a wide range of hazards. Documentation of the waste composition and of the exact burial locations are incomplete. Technological solutions are therefore needed for the following specific characterization problems:

- Methods to determine the exact location of waste items that are particularly hazardous (e.g., high radiation level items, containers with a high content of fissile materials) or difficult to deal with (e.g., very large waste items)

- Methods to determine precise boundaries of pits

- Methods to locate buried containers that are outside pit boundaries

- Methods to determine the depth from grade to the top of the waste, to the bottom of the pit, and to the bedrock

- Methods to determine or project the deteriorated condition of the waste container

- Methods to determine or reconstruct the exact composition of certain types of wastes (e.g., sludges).

\section{Rotricval}

The buried waste to be retrieved is highly heterogeneous and contains a wide range of hazards. Technological solutions are therefore needed for the following specific retrieval problems:

- Methods for contamination control of soil containing casily aerosolized radioactive and/or hazardous substances

- Methods for retrieving significant amounts of fissile materials

- Methods for preparing a useable pit floor on which retrieval equipment can operate

- Methods for retrieving waste items that vary greatly in size 
- Methods for protecting retrieval workers from the hazards of toxic chemicals, airborne contamination, and radiation

- Methods for minimizing the self-generation of waste during retrieval operations.

\section{Pre-Processing/Separation}

The retrieved mixture may consist of waste containers, highly heterogencous loose waste, contaminated soil, aqueous waste or mud, etc. Technological solutions are therefore needed for the following problems in pre-processing/separating waste:

- Methods for separation of soil from waste

- Methods for dealing with a soil/waste mixture that may be highly viscous

- Methods for assaying lissile materials in a highly contaminated environment.

\section{Treatment}

Several types of retrieved waste, such as TRU waste, LLW, GTCC waste, and mixed hazardous waste, may require treatment. Different requirements for the product waste form may apply to each type. The waste requiring treatment is also expected to be highly heterogeneous (within a waste type) and to contain a wide range of hazards. Although no specific problems are listed here, technological solutions are needed for the treatment of a wide range of wastes to better enable DOE sites to safely remediate the waste.

\section{Storage}

The various types of retrieved waste, with or without treatment, may require storage. Different sets of requirements are applicable to the storage of various types of waste. Consecuently, technolugical solutions are needed for the following examples of storage problems:

- Methods for low-cost RCRA-approved storage

- Methods for packaging waste for interim sitorage

- Methods for coordinating compliance with RCRA/CERCLA/DOE and other regulatory requirements related to storage.

\section{Transportation}

The various types of retrieved waste may require on-site or off-site transport, in compliance with a range of Department of Transportation packaging and transport requirements. Although no specific problems are listed here, technological solutions are needed for a wide range of packaging and transport problems. 


\section{Disposal}

The various types of retrieved waste may require disposal in a variety of facilities, meeting a wide range of disposal requirements. Therefore, technological solutions are needed for the following examples of disposal problems:

- Methods for packaging waste in space-efficient containers to minimize disposal space requirements

- Strategies to optimize the number of post-retrieval waste types requiring disposal. 

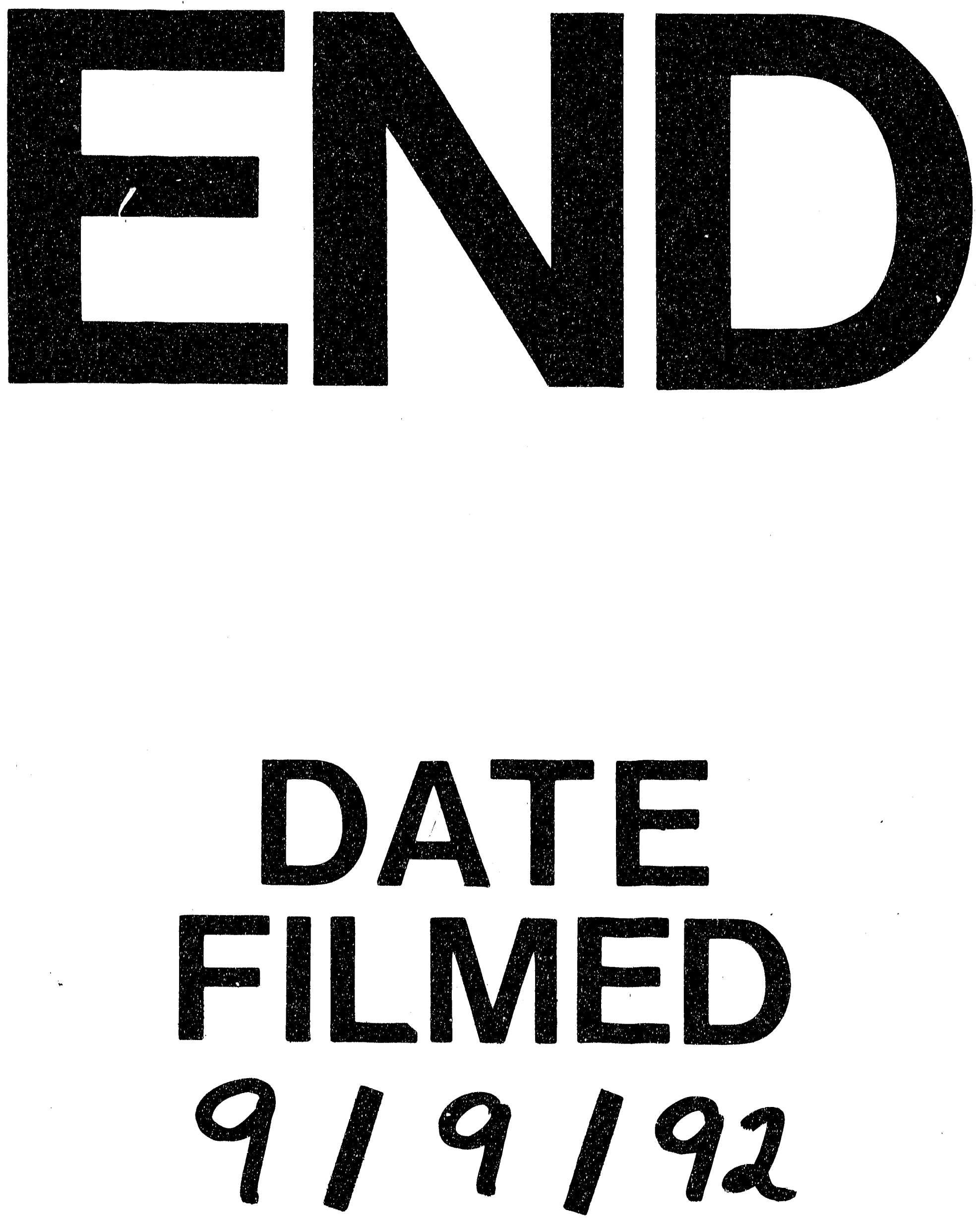

$\exists$ 
